\title{
Allelopathic effect of Wedelia trilobata L., on the germination and growth of Cicer arietinum, Vigna unguiculata, and Vigna radiata seedlings
}

\author{
S. Shahena, Maya Rajan, Vinaya Chandran, Linu Mathew* \\ School of Biosciences, Mahatma Gandhi University, Kottayam, Kerala, India.
}

\begin{tabular}{|c|c|}
\hline ARTICLE INFO & ABSTRACT \\
\hline $\begin{array}{l}\text { Article history: } \\
\text { Received on: May 25, } 2020 \\
\text { Accepted on: November 20, } 2020 \\
\text { Available online: March 10, } 2021\end{array}$ & $\begin{array}{l}\text { Allelopathy describes a natural process in biotic communities, wherein a plant species suppresses the growth and } \\
\text { establishment of neighboring flora. Such plants can be used as sources of allelochemicals to control weeds. The } \\
\text { proposed work evaluated the allelopathic activity of Wedelia trilobata L., against the seed germination and seedling } \\
\text { growth of Cicer arietinum (chickpea), Vigna unguiculata (cowpea), and Vigna radiata (green gram) by the leaf }\end{array}$ \\
\hline $\begin{array}{l}\text { Key words: } \\
\text { Wedelia trilobata L., } \\
\text { Cicer arietinum, } \\
\text { Vigna unguiculata, } \\
\text { Vigna radiata, } \\
\text { Allelopathy, } \\
\text { Allelochemicals, } \\
\text { Herbicides }\end{array}$ & $\begin{array}{l}\text { extracts of } W \text {. trilobata L., by Petri dish bioassay. Inhibition in shoot and root growth and fresh and dry weights was } \\
\text { tested by one-way analysis of variance. The aqueous extract of Wedelia significantly inhibited the growth of pulse } \\
\text { seedlings with a more pronounced effect at higher concentrations. Further, bioassay-guided fractionation yielded } \\
\text { the petroleum ether extract showing maximum growth inhibition indicating the non-polar nature of the allelopathic } \\
\text { compound. This extract was further fractionated, and the allelo-compounds were identified by HR-LCMS- MSMS- } \\
\text { QTOF analysis as 9-amino-nonanoic acid, colforsin, artelinic acid, Osthol, 4-Nonylphenol, Lagochilin, and } \\
\text { Ophiobolin A. The present study suggested a promising tool for controlling weeds through allelopathic compounds } \\
\text { isolated from Wedelia, which can be used as natural herbicides that are less disruptive to the ecosystem. }\end{array}$ \\
\hline
\end{tabular}

\section{INTRODUCTION}

Higher plants mediate plant to plant eco-physiological interactions by synthesizing secondary metabolites called allelochemicals. When released into the environment from the host plant, they influence the development and growth of its neighbors [1]. These compounds do not hamper the primary metabolism that is essential for the host plants for their survival [2]. They are present in almost all plant tissues of the hosts [3].

Weeds hamper human activity in both crop and non-crop areas. They fight with the standing crop for nutrition and other resources and hinder the overall crop growth and development. Eventually, this causes a qualitative and quantitative reduction in the crop yield [2]. A successful invasion of a weed in any ecosystem is the result of enhanced growth and reproductive potential, adaptive character, and other interferences due to the drop in available resources and, by allelopathy $[4,5]$.

Allelopathy is essential in the plant incursion process. The absence of co-evolved tolerance to new chemicals produced by the aggressors by the existing native vegetation allows these invaders to dominate natural

*Corresponding Author: Linu Mathew,

School of Biosciences, Mahatma Gandhi University,

Kottayam - 686 560, Kerala, India.

E-mail:linumathew@mgu.ac.in ecosystems [6]. The chemicals or secondary metabolites produced by the host plant responsible for the allelopathic effects are termed as allelochemicals. The allelochemicals may enhance the successful establishment and reproduction of the beneficiaries [7,8]. Root exudation, volatilization, the decay of the plant matter, and leaching of plant foliage are the processes which discharge these allelochemicals to the environment $[9,10]$. Allelochemicals are bio-communicators since living organisms use them to exchange growth signals [11].

The most important pathway of releasing allele-chemicals is by root exudation. The root exudates determine the bioavailability and phytotoxicity of allelochemicals; by interacting with the inorganic and organic soil components and soil microorganisms [12]. The phytotoxic levels of these compounds in the soil are determined by the prevailing soil conditions and the physical, chemical, and biological transformations of allelochemicals in the soil environment [13-15].

Allelopathy supplies a less laborious and effective biological alternative to chemical and mechanical methods of weed control without affecting the environment adversely [16]. It has presented an alternative for developing eco-friendly agricultural practices, enhancing crop productivity, and maintaining ecosystem stability [10]. Moreover, allelopathic interactions may be significant in ecosystems by influencing weed control and crop productivity [17]. Modern agricultural systems depend on synthetic herbicides to provide protection against weeds which results in 
severe environmental hazards, including the production of herbicideresistant plants [18]. Thus, allelopathy can be used as an alternative natural strategy which protects crops against competing plants, and allelochemicals can be used as natural weedicides which are safe to the ecosystems [19].

Wedelia trilobata (L.) Hitche (Sphagneticola trilobata) is a perennial evergreen creeper of the family Asteraceae [20]. This plant is a harmful invasive weed with deleterious effects on surrounding plants. The harmful effect of allelopathic compounds of W. trilobata to crop plants is due to the presence of various bioactive compounds with extensive biological activities [21]. It was introduced as an ornamental garden plant, and its invasion has now caused significant damage to the natural ecosystem and biodiversity in South India. IUCN (2001) [22] listed $W$. trilobata as one of the worst invasive alien weed. The successful incursion of $W$. trilobata is due to its high reproduction, broad ecophysiological adaptations, and more often, due to its allelopathic effects on adjacent native plants also [23].

The most common procedure of evaluating allelopathy is by studying the inhibition of growth and germination of seedlings of crop plants and weeds by aqueous, alcoholic, or other extracts of the allelopathic plant [24]. Hence, the present study was designed as a preliminary donor-receiver bioassay to decide the possible allelopathic effect of different extracts of leaves of $W$. trilobata against the growth of pulses such as Cicer arietinum (chickpea), V. unguiculata (cowpea), and Vigna radiata (green gram) through growth inhibition and to isolate allelo-compounds from this plant.

\section{MATERIALS AND METHODS}

\subsection{Collection of Donor Plant}

The weed $W$. trilobata was selected as a donor plant. The fresh plants of W. trilobata were collected from the Mahatma Gandhi University campus, Kottayam, Kerala, India. The plant was identified, and a voucher specimen (Accession no: 7637) was deposited at Regional Herbarium, Kerala, at St. Berchmans College, Changanassery, Kerala, India.

\subsection{Selection of Receiver Plant}

C. arietinum (Chickpea), V. unguiculata L. (Cowpea), and V. radiata L. (Green gram) were selected as receiver plants. The seeds of these plants were sourced from the local market of Kottayam, Kerala, India.

\subsection{Preparation of Plant Extract}

\subsubsection{Aqueous extract for checking the allelopathic effect}

The aqueous extract, prepared from the fresh leaves of the donor plants, was used for the present analysis. After washing thoroughly with tap water, $100 \mathrm{~g}$ of the fresh leaves of the W. trilobata were hand crushed and soaked in $100 \mathrm{ml}$ distilled water. After keeping at room temperature for $24 \mathrm{~h}$, the extract was filtered through a sieve and considered as $100 \%$ stock for further analysis. By diluting the stock with distilled water, other concentrations such as $25 \%, 50 \%$, and $75 \%$ were prepared. Distilled water without the plant extract was used as the control.

\subsubsection{Preparation of donor seedlings}

The fresh seeds were washed thoroughly and soaked in tap water overnight at room temperature. Seeds showing signs of germination were used for the analysis.

\subsubsection{Germination by Petri-dish bioassay}

Sterile Petri plates (12 cm diameter) were used for the bioassay. A Whatman No.1 filter paper kept on the Petri dish was moistened with the plant extract according to the required concentration. A control moistened with distilled water was also kept. Ten germinating seeds were placed over the Petri plate and grown for 7 days. The plates were wetted daily with the same concentration of plant extract for getting the favorable moisture content for the growing seeds. Only those seeds with complete radical emergence are considered to be fully germinated. The experiments were repeated thrice with the daily recording of the data.

\subsubsection{Growth inhibition by organic solvent extracts}

Different solvent extracts were prepared by sequential cold extraction of the dried leaf powder for $48 \mathrm{~h}$. As per Ma et al., 2014 [25], growth inhibition assay of germinated seeds by petroleum ether, chloroform, ethyl acetate, and methanol extracts and column chromatographic fractions was done. Briefly, $50 \mu 1$ of extracts or fractions dissolved in acetone was mixed with $1.0 \mathrm{~mL}, 0.5 \%$ agar gel. The controls contained the same amount of acetone in $0.5 \%$ agar gel. Ten germinated seeds of pulses were placed in the agar media and grown in an illumination incubator at $27^{\circ} \mathrm{C}$ with a photoperiod of $12: 12 \mathrm{~h}$ for 3-4 days. Treatments were repeated thrice.

\subsection{Germination Percentage}

The percentage of the germination was calculated as follows.

Germination $\%=$ No. of seeds germinated $/$ Total no. of seeds sown $\times 100$

\subsection{Growth of the Seedlings}

The growth of the seedlings was estimated by measuring the shoot and root length of 5 randomly selected plants, and the average values were taken as $\mathrm{cm} /$ plant.

\subsection{Fresh and Dry Weights}

Five randomly collected seedlings from the control and treatment groups after 7 days of incubation were assayed for fresh and dry weight. The fresh weight of each sample was taken with the help of an analytical weighing balance and recorded in $\mathrm{g} /$ plant. Then, they were placed in a hot air oven at $80^{\circ} \mathrm{C}$ until the constant dry weight was obtained, which was recorded as g/plant.

\subsection{Statistical Analysis}

The experiments were carried out thrice. The means were expressed as mean \pm SE. One-way analysis of variance was done using IBM SPSS Statistics, Version 20. The mean comparison was made by the least significant difference (LSD) at $\mathrm{p} \leq 0.05$.

\subsection{Extraction of Active Allelo-compounds}

The petroleum ether extract was subjected to column fractionation with silica gel as the stationary phase and hexane:ethyl acetate $(3: 1)$ as mobile phase. The fractions ( $\mathrm{C} 1$ to $\mathrm{C}-13)$ were further subjected to seed germination bioassay. The fraction showing the highest inhibition was analyzed by HR LCMS- MSMS- QTOF analysis (Syncronis C18 100 $\times 2.1$, particle size $1.7 \mathrm{u}$ ).

\section{RESULTS AND DISCUSSION}

Allelopathy plays a fundamental part in the maintenance of biodiversity and the natural resource base of vulnerable ecosystems. Furthermore, 
it has roles in sustainable agriculture by expanding the range of weed management practices.

The Petri dish bioassay of the aqueous leaf extract of W. trilobata showed that the highly invasive weed $W$. trilobata is a promising allelopathic plant as they inhibit seed germination in selected pulse varieties such as $C$. arietinum, $V$. unguiculata, and $V$. radiata. $W$. trilobata extracts significantly inhibited seed germination [Figure 1-3]. They also reduced shoot and root length and fresh and dry weight of the pulse seedlings, which was comparable to the inhibition by the extracts of Eucalyptus [26] and Tridax procumbens L. [2]. Allelopathy is positively associated with other environmental stresses such as pests and diseases, extremes of temperature, nutrient starvation, and water stress, and stress due to radiation and herbicides. Such stressed circumstances frequently boost the production of allelochemicals and potential for allelopathic interference. This makes the host plant more successful in a stressed environment [27].

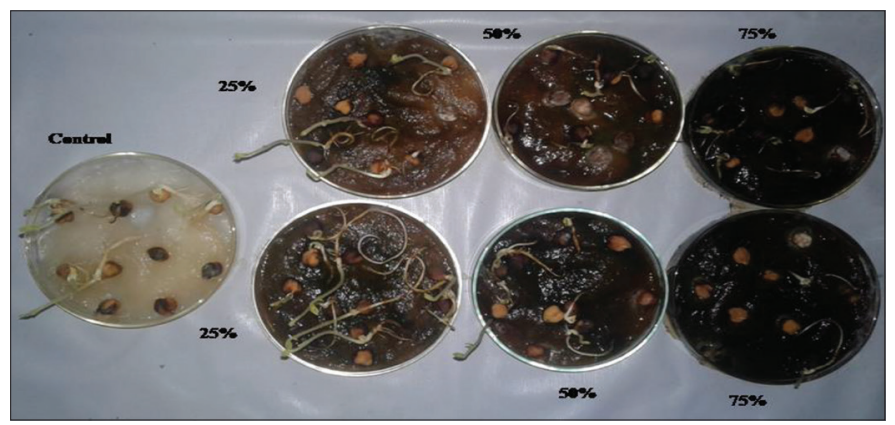

Figure 1: Allelopathic effect of Wedelia trilobata on seed germination of Cicer arietinum.

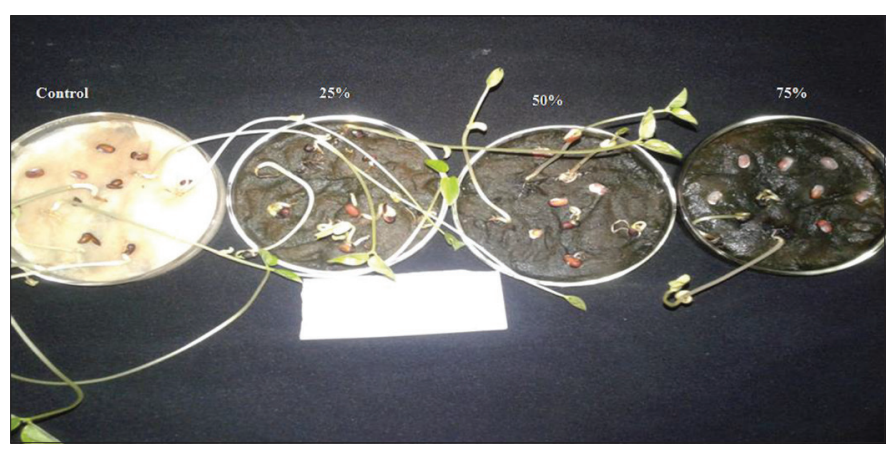

Figure 2: Allelopathic effect of Wedelia trilobata on seed germination of Vigna unguiculata.

\subsection{Seed Germination}

The germination of the C. arietinum, $V$. unguiculata, and $V$. radiata was significantly affected by the $W$. trilobata extract with more pronounced inhibition at high concentrations. Among the three varieties, the germination of the $C$. arietinum seeds showed the highest inhibition against the water extract in every tested concentration [Figure 4]. V. unguiculata showed a moderate level of inhibition, and $V$. radiata was the least inhibited as compared to other varieties in a concentration-dependent manner. A steady decrease in germination percentage in the presence of $W$. trilobata extracts was noticed from low to high concentrations in comparison to control, indicating the concentration-dependent nature of inhibition.

Germination percentage is considered to be an excellent indicator for the detection of allelopathic potential [28]. It is also used for the assessment of the effects of chemical compounds in the laboratory or the field [29]. The process of seed germination is complex and involves sequential changes in biochemistry, physiology, and morphology of the seedlings. Disruption of these changes results in hampering proper germination and growth. The presence or absence of some chemical compounds mediates this inhibition [28]. The leaf extracts of Conocarpus lancifolius (Engl.) held up germination and growth of Vigna sinensis L. and Zea mays L. in a concentrationdependent manner [30]. Furthermore, the leaf extracts of Brassica nigra [31], Eucalyptus camaldulensis [32], Acacia auriculiformis [33], and alfalfa [34] inhibited the germination and growth of some crops.

The strength of the aqueous extract had a significant role in declining water uptake essential for seed germination [30]. The osmotic stress imparted by the leaf extracts might lead to the differences in water uptake by the seedlings [35]. Germination was high in the control and treatments with low extract concentrations. Hence, water uptake might have played a role in lessening the germination inhibition due to the low osmotic potential of the extracts at low concentrations. A great many metabolic and physiological changes during seed germination could be related to water uptake [36]. Even though the biochemical processes inhibiting the germination were not clearly defined, allelochemicals in the leaf extract might have a role in increasing respiration and hydrolytic enzyme activity leading to low cell division and embryo enlargement [37].

\subsection{Shoot and Root Length}

The fresh leaf extracts of $W$. trilobata L. significantly affected the shoot and root lengths of $C$. arietinum, $V$. unguiculata, and $V$. radiata seedlings [Table 1]. The lowest shoot and root lengths were recorded in

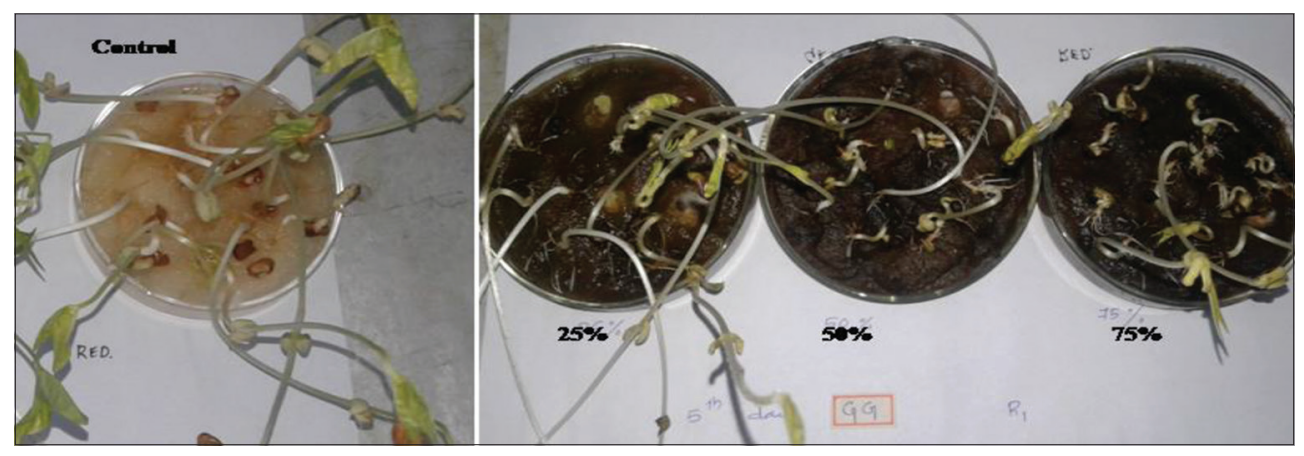

Figure 3: Allelopathic effect of Wedelia trilobata on seed germination of Vigna radiate. 
C. arietinum, and the highest values were in V. radiata. The inhibition was found to be purely in a concentration-dependent manner. Moreover, the aqueous leaf extracts of Tectona grandis L. inhibited the seed germination and seedling growth of Vigna mungo (L.) [38]. Here, it is postulated that the aqueous Wedelia leaf extract might have affected the root and root related metabolic activities, leading to a decrease in the healthy shoot growth by denying water and nutrients. Furthermore, it might have restricted the photosynthetic activities, with a resultant lack of resources and energy needed for normal growth. Moreover, leaf etiolation and nanism were reported in plants treated with $W$. trilobata extracts [39].

The treated pulse seedlings possessed characteristic variations in their root length as compared to the control plants. Some seedlings showed a high specific root length in comparison to the shoot length, and some others had stunted roots. Reports suggested that these are characteristics of plants growing in sterile environments or being exposed to environmental stress [40].

\subsection{Fresh and Dry Weight}

After 7 days of treatment, the extracts from the fresh leaves of the W. trilobata L. decreased the fresh and dry weight of C. arietinum, $V$. unguiculata, and $V$. radiata [Table 2]. Even though significant reductions were found in all tested concentrations, the effect was concentration and species-dependent. The highest inhibition was

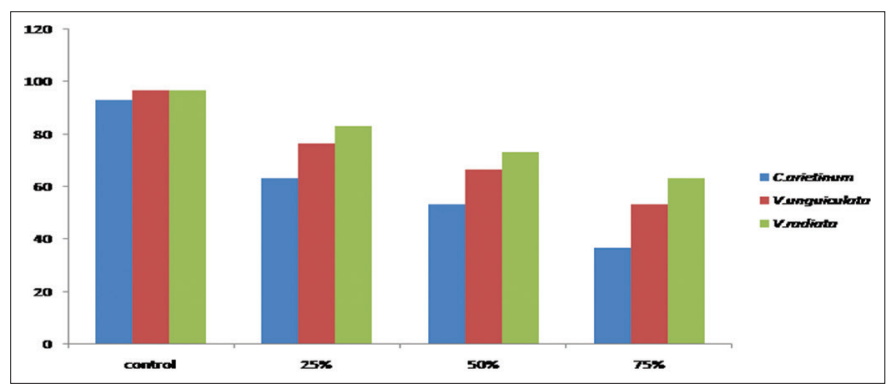

Figure 4: Graph bars represent allelopathic effect of different concentrations of Wedelia trilobata extract on the percentage of seed germination in Cicer arietinum, Vigna unguiculata, and Vigna radiata. shown by $75 \%$ of the extract concentration, and the least inhibition was at $25 \%$. Growth inhibition was the least in $V$. radiata. The inhibition was found to be the highest in $C$. arietinum and $V$. unguiculata showed a moderate level of inhibition. The reduction in metabolic activities of the aerial and underground plant parts might have caused a substantial drop in the fresh and dry weights of the treated seedlings. The leaf extracts of Tephrosia purpurea, Albizia amara, and Delonix regia caused a decrease in the biomass of maize [41], and the aqueous extracts of the leaves of $T$. grandis caused a concentration-dependent reduction in the biomass of V. mungo [38].

The germination and growth are considered as the outcome of cell division. Flavonoids and phenolic compounds in the Zygophyllum album had an inhibitory effect on cell division and held-up mitosis [42]. Moreover, the water extracts of Z. simplex L. suppressed the production of DNA and nucleoproteins of Vicia faba L. [43]. Furthermore, high concentrations of Aloe vera L. extract significantly altered the cell division and growth rate of Allium cepa L. [44]. Here also, we can surmise that Wedelia extract might have inhibited the growth of pulse seedlings by suppressing mitosis in the donor plant.

\subsection{Extraction of Active Allelo-compounds}

High metabolic rate is the characteristic feature of seedling growth; therefore, it is highly susceptible to allelopathy $[45,46]$. Petroleum ether extract significantly reduced germination percentage and the growth rate of the C. arietinum as compared to other extracts. All the tested parameters such as shoot and root lengths and fresh and dry weights were affected by the petroleum ether extract [Figures 5-8]. The rate of inhibition was in the order petroleum ether $<$ chloroform $<$ ethyl acetate $<$ methanol. The non-polar nature of the inhibitor was evidenced by the high inhibition shown by the petroleum ether and chloroform extracts [47].

The allelopathic activities of Ampelocissus latifolia (Roxb.) Planch. leaf extracts correlated qualitatively and quantitatively with the useful phytochemicals and the solvents used for the extraction [46]. Here, the column fraction C3 was inhibitory as compared to other fractions in seed germination bioassay

Table 1: The effects of aqueous leaf extract of Wedelia trilobata on shoot length and root length of $C$. arietinum, $V$. unguiculata, and $V$. radiata.

\begin{tabular}{|c|c|c|c|c|c|c|}
\hline \multirow[t]{2}{*}{ Treatment } & \multicolumn{2}{|c|}{ C. arietinum } & \multicolumn{2}{|c|}{ V. unguiculata } & \multicolumn{2}{|c|}{ V. radiate } \\
\hline & $\begin{array}{l}\text { Shoot length }(\mathrm{cm}) \\
\text { Mean } \pm \text { Std. Error }\end{array}$ & $\begin{array}{l}\text { Root length }(\mathrm{cm}) \\
\text { Mean } \pm \text { Std. Error }\end{array}$ & $\begin{array}{l}\text { Shoot length }(\mathrm{cm}) \\
\text { Mean } \pm \text { Std. Error }\end{array}$ & $\begin{array}{l}\text { Root length }(\mathrm{cm}) \\
\text { Mean } \pm \text { Std. Error }\end{array}$ & $\begin{array}{l}\text { Shoot length }(\mathrm{cm}) \\
\text { Mean } \pm \text { Std. Error }\end{array}$ & $\begin{array}{l}\text { Root length }(\mathrm{cm}) \\
\text { Mean } \pm \text { Std. Error }\end{array}$ \\
\hline \multirow[t]{3}{*}{ Control } & $4.2200 \pm 0.5054^{\mathrm{a}}$ & $2.6400 \pm 0.3171^{\mathrm{a}}$ & $17.3400 \pm 2.0114^{\mathrm{a}}$ & $4.9000 \pm 0.3066^{\mathrm{a}}$ & $23.3000 \pm 0.8602^{\mathrm{a}}$ & $6.1800 \pm 0.2615^{\mathrm{a}}$ \\
\hline & $4.2200 \pm 0.5054^{\mathrm{a}}$ & $3.1200 \pm 0.2245^{\mathrm{a}}$ & $18.4600 \pm 1.9472^{\mathrm{a}}$ & $5.0600 \pm 0.4833^{\mathrm{a}}$ & $21.600 \pm 0.7218^{\mathrm{a}}$ & $5.1600 \pm 0.5046^{\mathrm{a}}$ \\
\hline & $4.9000 \pm 0.1975^{\mathrm{a}}$ & $2.5000 \pm 0.2000^{\mathrm{a}}$ & $15.3600 \pm 1.5481^{\mathrm{a}}$ & $6.3400 \pm 0.5409^{\mathrm{a}}$ & $19.5800 \pm 1.5907^{\mathrm{a}}$ & $6.8400 \pm 1.0755^{\mathrm{a}}$ \\
\hline \multirow[t]{3}{*}{$25 \%$} & $2.2800 \pm 0.4212^{\mathrm{bc}}$ & $1.2000 \pm 0.2214^{\mathrm{bc}}$ & $10.6800 \pm 1.9787^{\mathrm{bc}}$ & $3.2600 \pm 0.1030^{\mathrm{b}}$ & $15.9000 \pm 0.6626^{\mathrm{b}}$ & $3.8600 \pm .12884^{\mathrm{b}}$ \\
\hline & $2.1800 \pm 0.2478^{b}$ & $1.8000 \pm 0.3507^{b}$ & $13.3400 \pm 1.7348^{\mathrm{b}}$ & $3.3200 \pm 0.2782^{\mathrm{b}}$ & $14.3600 \pm 0.8358^{b}$ & $3.7000 \pm 0.5550^{\mathrm{b}}$ \\
\hline & $2.0400 \pm 0.1600^{\mathrm{b}}$ & $1.5600 \pm 0.1600^{\mathrm{b}}$ & $10.0200 \pm 1.0538^{\mathrm{b}}$ & $3.7800 \pm 0.5953^{\mathrm{b}}$ & $13.9000 \pm 1.5959^{\mathrm{b}}$ & $4.6600 \pm 0.4885^{\mathrm{b}}$ \\
\hline \multirow[t]{3}{*}{$50 \%$} & $1.2400 \pm 0.2874^{\mathrm{c}}$ & $0.8000 \pm 0.1414^{\mathrm{cd}}$ & $6.5000 \pm 1.4188^{c}$ & $2.1000 \pm 0.0707^{c}$ & $10.9800 \pm 0.5142^{c}$ & $2.6000 \pm 0.1140^{c}$ \\
\hline & $1.0400 \pm 0.0510^{\mathrm{c}}$ & $0.9800 \pm 0.2177^{\mathrm{c}}$ & $8.2000 \pm 0.9940^{c}$ & $1.9000 \pm 0.2569^{c}$ & $8.2000 \pm 0.9940^{\mathrm{c}}$ & $1.9600 \pm 0.2839^{c}$ \\
\hline & $0.8800 \pm 0.0374^{\mathrm{c}}$ & $0.9200 \pm 0.0490^{c}$ & $5.7000 \pm 0.8149^{c}$ & $2.0600 \pm 0.3641^{\mathrm{c}}$ & $8.6400 \pm 1.0357^{\mathrm{c}}$ & $3.8200 \pm 0.2596^{\mathrm{bc}}$ \\
\hline \multirow[t]{3}{*}{$75 \%$} & $0.4200 \pm 0.1241^{\mathrm{cd}}$ & $0.2000 \pm 0.0633^{\mathrm{d}}$ & $3.9800 \pm 1.0205^{\mathrm{cd}}$ & $1.1400 \pm 0.1749^{\mathrm{d}}$ & $7.6400 \pm 0.2874^{\mathrm{d}}$ & $1.3200 \pm 0.0800^{\mathrm{d}}$ \\
\hline & $0.1800 \pm 0.0374^{\mathrm{d}}$ & $0.3400 \pm 0.0678^{c}$ & $3.9000 \pm 0.4278^{\mathrm{d}}$ & $0.7800 \pm 0.0735^{\mathrm{d}}$ & $5.5000 \pm 0.2168^{\mathrm{d}}$ & $1.2000 \pm 0.1897^{\mathrm{c}}$ \\
\hline & $0.2800 \pm 0.0860^{\mathrm{d}}$ & $0.2800 \pm 0.0583^{\mathrm{d}}$ & $1.9000 \pm 0.3317^{\mathrm{d}}$ & $0.9400 \pm 0.1691^{\mathrm{c}}$ & $3.8400 \pm 0.7243^{\mathrm{d}}$ & $2.1600 \pm 0.4226^{\mathrm{c}}$ \\
\hline
\end{tabular}

The table represents mean of three replicates \pm SE between the two treated groups at $P<0.05$ level. The mean with same letter is not significantly different according to Duncan's multiple range test $(P \leq 0.05)$. C. arietinum: Cicer arietinum, $V$. unguiculata: Vigna unguiculata, $V$. radiata: Vigna radiata 
Table 2: The effects of aqueous leaf extract of Wedelia trilobata on fresh and dry weight of C. arietinum, V. unguiculata, and V. radiata.

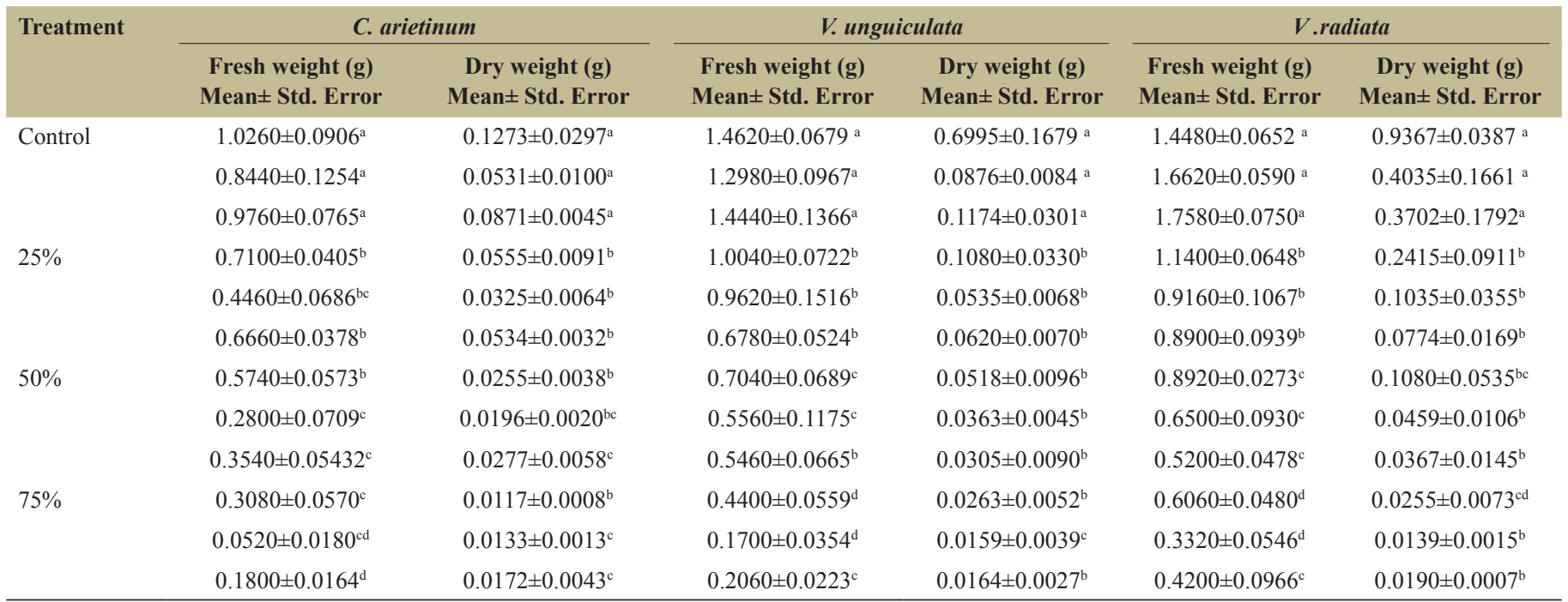

The table represents mean of three replicates \pm SE between the two treated groups at $P<0.05$ level. The mean with same letter is not significantly different according to Duncan's multiple range test $(P \leq 0.05)$. C. arietinum: Cicer arietinum, V. unguiculata: Vigna unguiculata, V. radiata: Vigna radiata

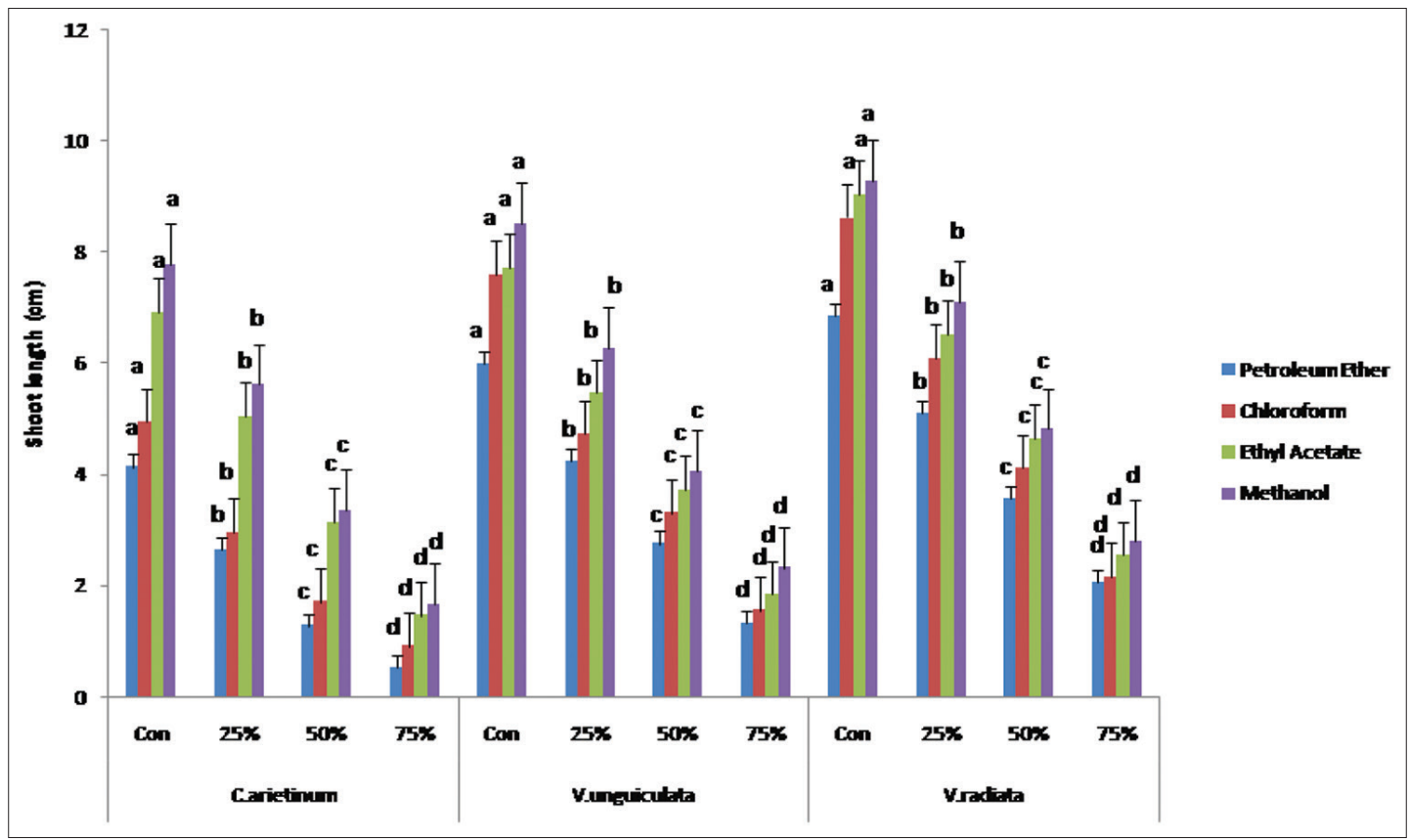

Figure 5: Graph bars represent allelopathic effect of concentrations of solvent extracts of Wedelia trilobata on shoot length of Cicer arietinum, Vigna unguiculata, and Vigna radiata. The figure represents mean of three replicates \pm SE between the treated groups at $P<0.05$ level. The mean with same letter is not significantly different according to Duncan's multiple range test $(P \leq 0.05)$.

[Figure 9]. HRLCMS- MSMS- QTOF analysis based metabolite profiling of petroleum ether column fraction $\mathrm{C} 3$ of $W$. trilobata detected around 100 compounds by positive ionization and 35 compounds by negative ionization with seven potentially active secondary metabolites with allelopathic effect [Supplementary Tables: Tables S1 and S2]. They include 9-amino-nonanoic acid, colforsin, artelinic acid, Osthol, 4-Nonylphenol (4-NP), Lagochilin, and Ophiobolin A [Table 3].

9-aminononanoic acid is an omega-amino fatty acid: Nonanoic acid substituted by an amino group at position 9. It is a metabolite derived from nonanoic acid. Cleome viscosa root exudates showed the presence of lactam nonanoic acid. The aqueous solution of this purified compound inhibited the growth of rice, gram, and mustard seeds in a concentration-dependent manner [48].

Cistus ladanifer is an allelopathic and autoallelopathic species due to the presence of flavonoids and diterpenes in the leaf exudates [49]. Colforsin is a water-soluble derivative of forskolin. Forskolin(coleonol), produced by the Indian Coleus plant (Plectranthus barbatus), is a labdane diterpene, and lagochilin is a bitter diterpene compound.

Artenilic acid is the semi-synthetic derivative of the natural compound artemisinin, which is used as a drug for the treatment 


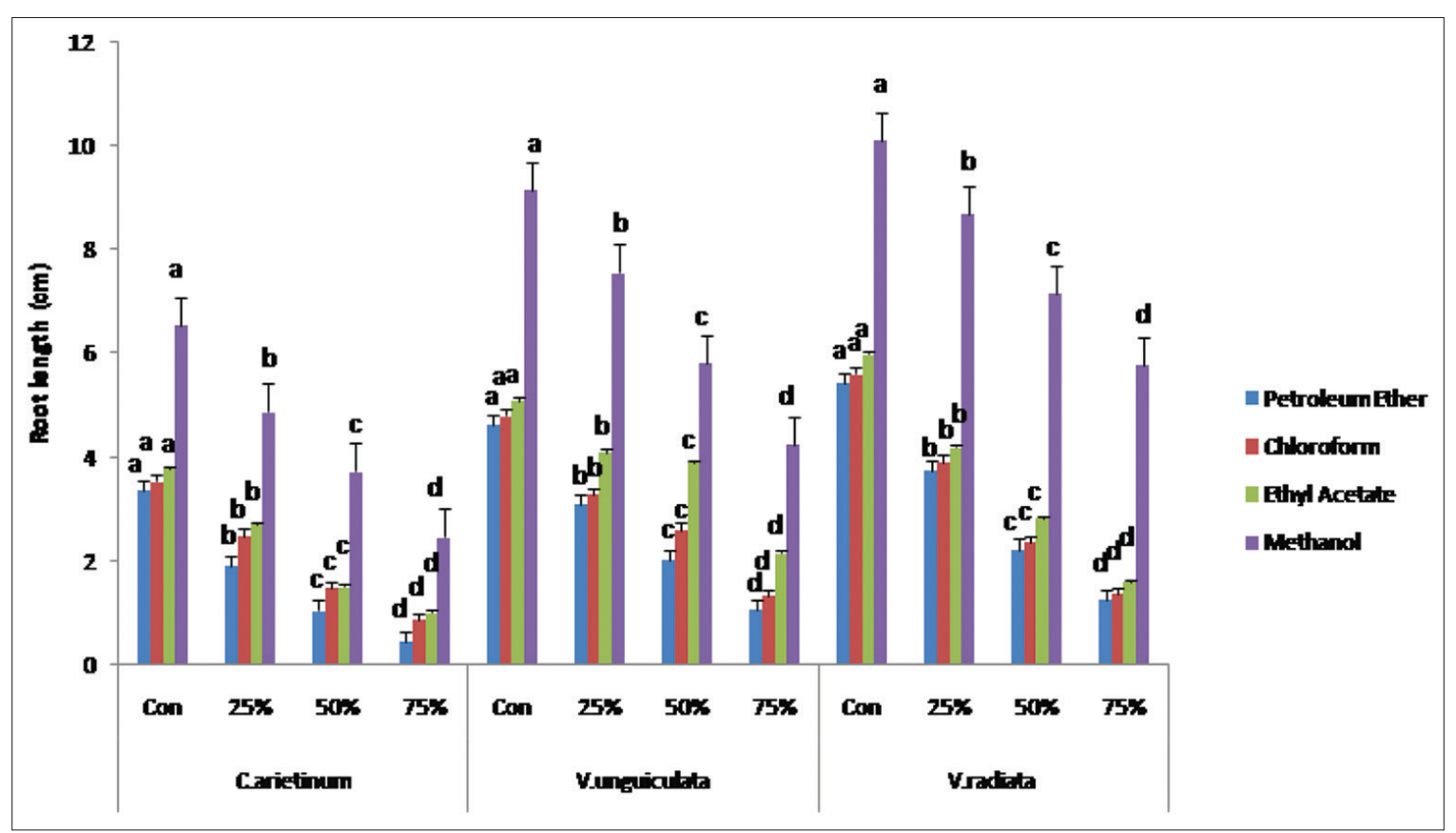

Figure 6: Graph bars represent allelopathic effect of concentrations of solvent extract of Wedelia trilobata on root length of Cicer arietinum, Vigna unguiculata, and Vigna radiata. The figure represents mean of three replicates \pm SE between the treated groups at $P<0.05$ level. The mean with same letter is not significantly different according to Duncan's multiple range test $(P \leq 0.05)$.

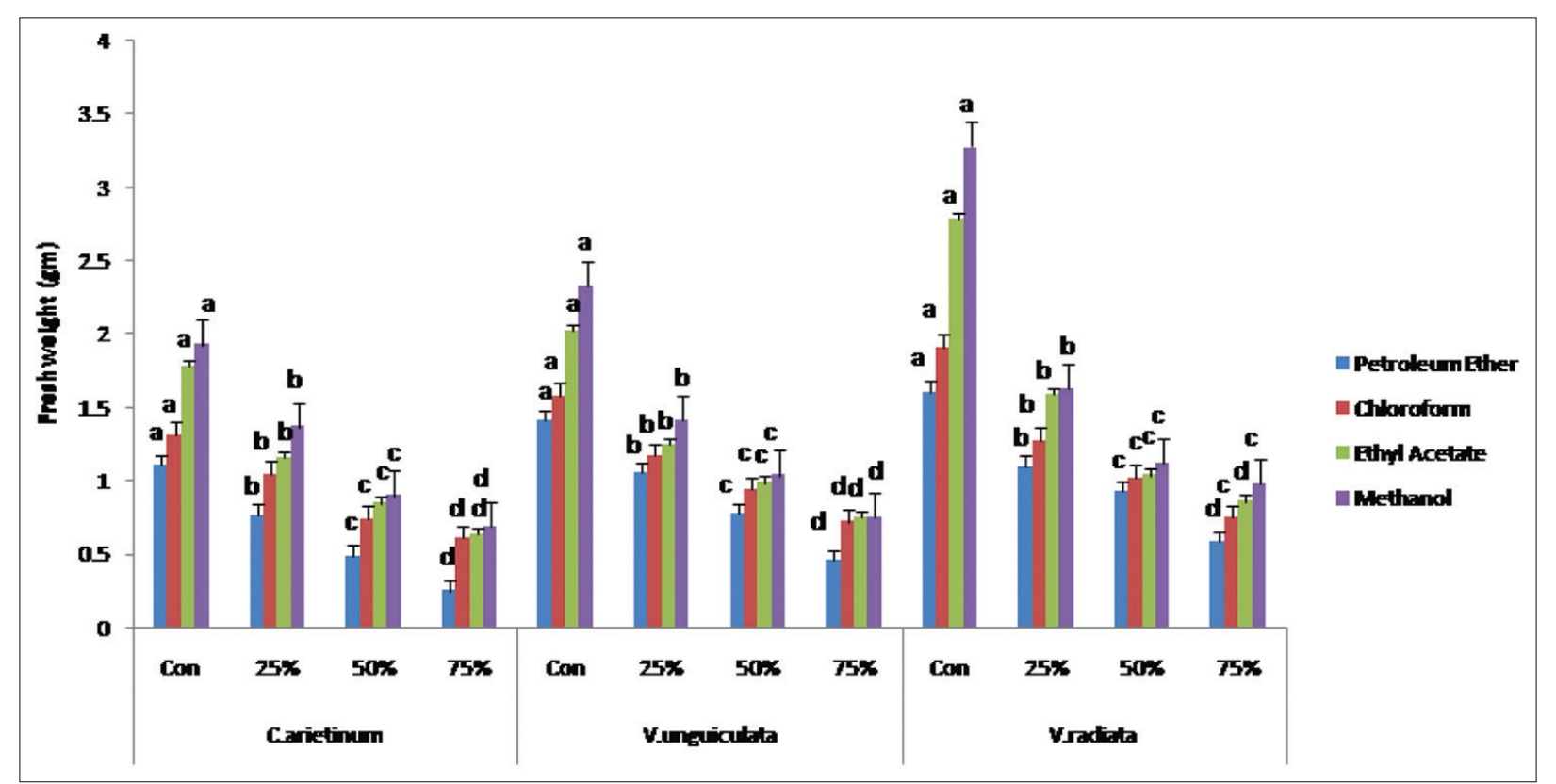

Figure 7: Graph bars represent allelopathic effect of concentrations of solvent extract of Wedelia trilobata on fresh weight of Cicer arietinum, Vigna unguiculata, and Vigna radiata. The figure represents mean of three replicates \pm SE between the treated groups at $P<0.05$ level. The mean with same letter is not significantly different according to Duncan's multiple range test $(P \leq 0.05)$.

of Malaria. It is obtained from Artemisia annua L. Large amounts of this antimalarial compound are released into soil ecosystems by rainwater leachate, root exudates, and decomposition of plant materials. It can inhibit plant growth around $A$. annua L. and microbial growth in soils [50].

Osthol is a derivative of coumarin. The leaf extracts of Gliricidia sepium (Fabaceae) inhibited the growth of lettuce (Lactuca sativa) radicles due to the presence of coumarins [51].
4-NP is an anthropogenic contaminant influencing the biotic and abiotic environmental factors [52].

Ophiobolin A found in the water extract and ethanolic extract of W. trilobata is a phytotoxic sesterpene $\left(\mathrm{C}_{25}\right)$ with potential as a natural herbicide against grass weeds [21,53].

The 9-amino-nonanoic acid, colforsin, artelinic acid, Osthol, 4-NP, Lagochilin, and Ophiobolin A in C3 column fraction of petroleum ether 


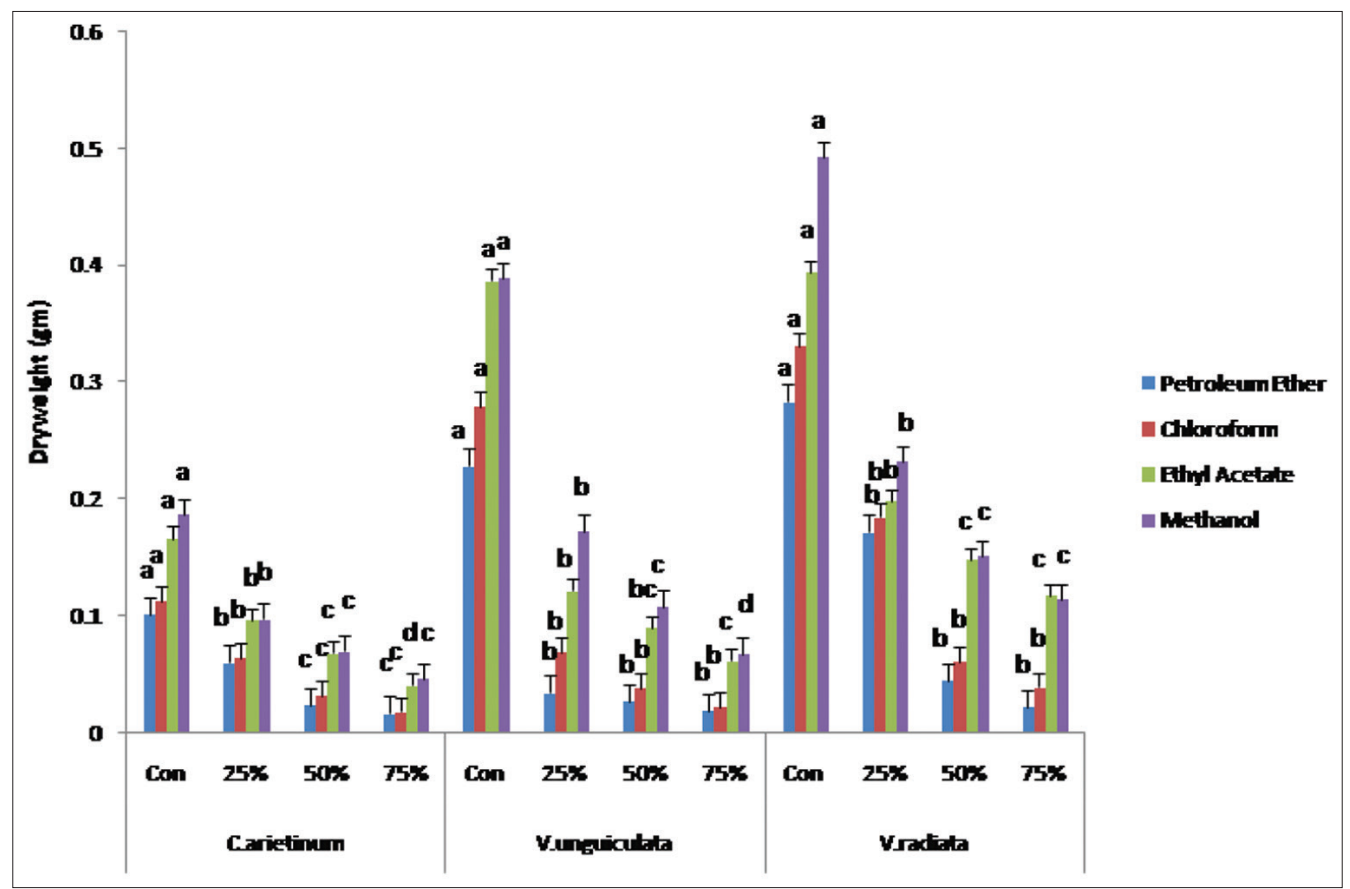

Figure 8: Graph bars represent allelopathic effect of concentrations of solvent extract of Wedelia trilobata on dry weight of Vigna arietinum, Vigna unguiculata, and Vigna radiata. The figure represents mean of three replicates \pm SE between the treated groups at $P<0.05$ level. The mean with same letter is not significantly different according to Duncan's multiple range test $(P \leq 0.05)$.

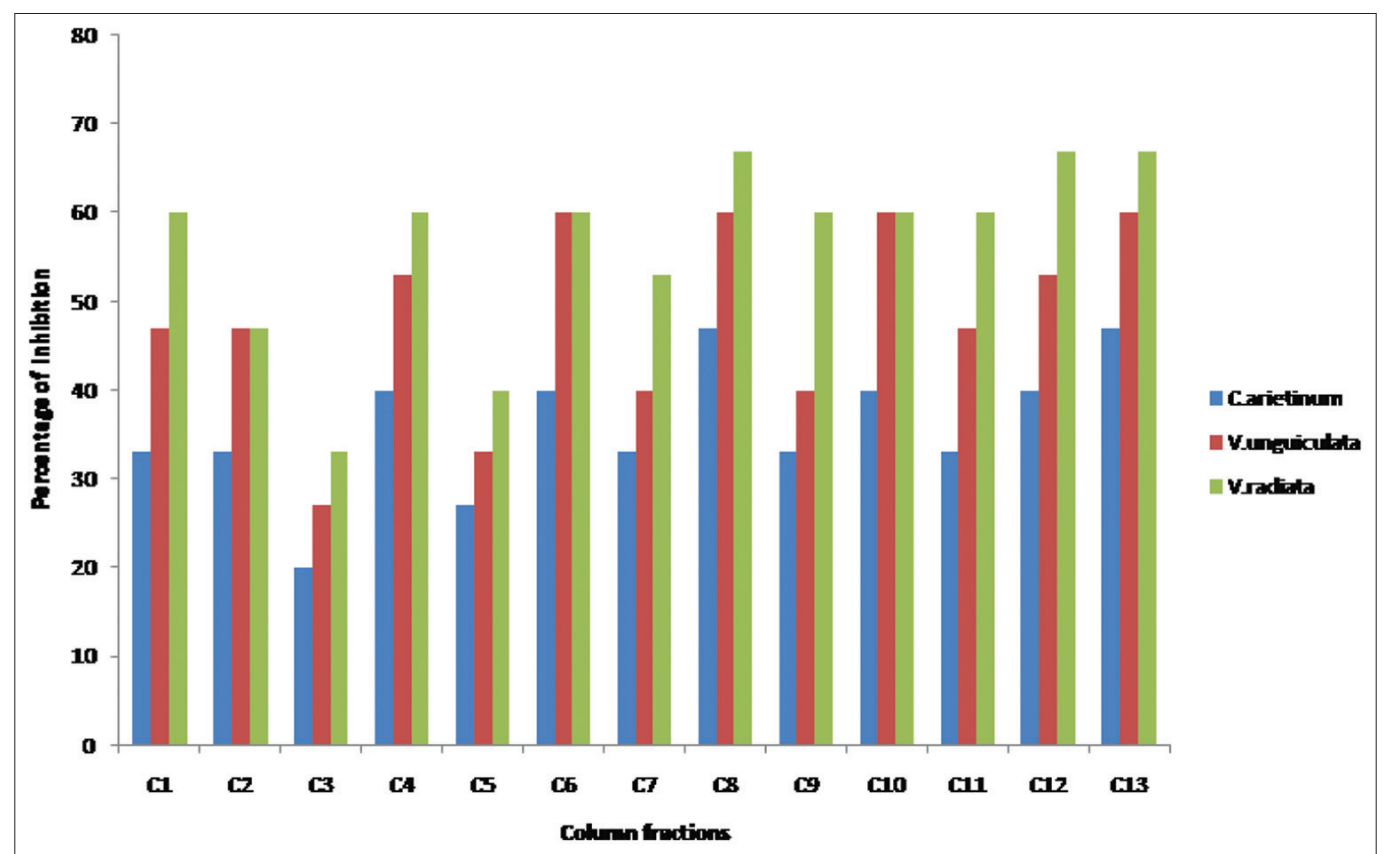

Figure 9: Graph bars represent allelopathic effect of column fractions of Wedelia trilobata extract on percentage of seed germination in Cicer arietinum, Vigna unguiculata, and Vigna radiata.

extract of $W$. trilobata reveals the presence of diterpenes, sesterpenes, coumarins, and various other metabolites and the presence and the combined effect of these compounds might be the reason for the allelopathy of $W$. trilobata.

The suppressive outcome of allelochemicals is remarkably reliant on their concentrations [54-56]. The contribution of chemical compounds in the allelopathy is prominent. Hence, the higher concentration of these chemical compounds results in a more pronounced effect on the target plant species. It is difficult to isolate the effect of a single chemical compound and blame it for growth hang-up as the allelopathy process is complicated [57]. Besides, this process may accompany other ecological influences like the microbial and chemical nature of the soil $[58,59]$. 
Table 3: Lists of compounds isolated by HR LCMS- MSMS- QTOF from $\mathrm{C} 3$ fraction of petroleum ether extract of Wedelia trilobata.

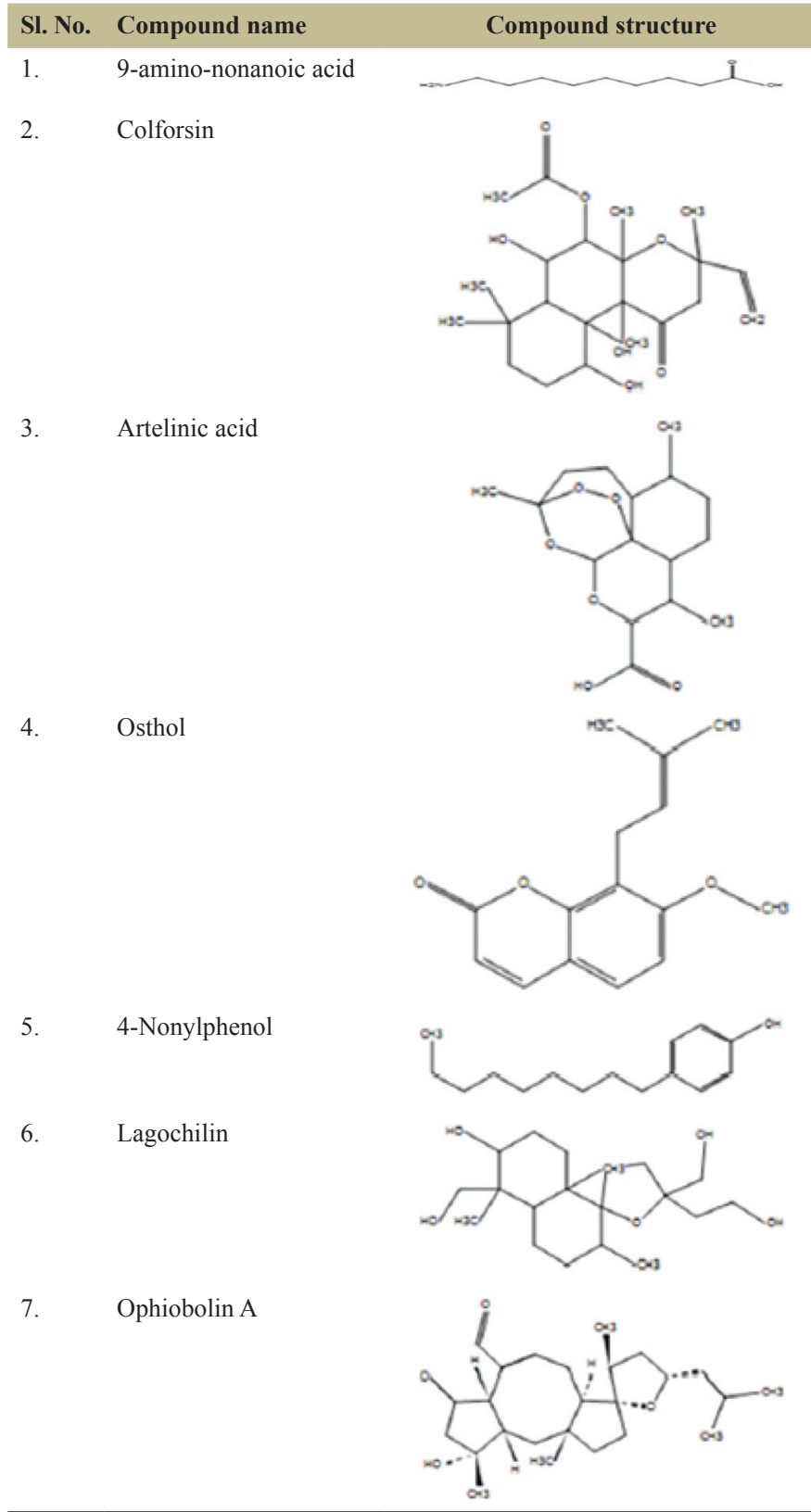

\section{CONCLUSION}

The present study indicated that even though all the tested pulse seedlings were inhibited by different $W$. trilobata extracts, they could bear stress up to a certain extent. Nevertheless, as the extract concentrations increased, a significant reduction in the tested parameters occurred in a concentration-dependent manner. The detrimental effects of the extracts indicated that the allelochemicals present in any concentration in the soil or as soil mulch could decrease the overall yield of the affected crops. The inhibitory effects are enhanced at high concentrations of the extracts, rather due to the combined effects of the compounds constituting the extract than a distinct component.

The presence of diterpene, sesterpenes, and coumarin derivatives along with sesquiterpene lactones was identified in the extracts of Wedelia leaves by HRLCMS- MS/MS- Q-TOF analysis. These compounds might have resulted in the allelopathic effect of $W$. trilobata $\mathrm{L}$. These compounds can be used for monitoring allelopathic interactions of $W$. trilobata and the presence of Osthol, a coumarin derivative, is reported for the $1^{\text {st }}$ time in the present study. Allelochemicals functions as biomarkers and they can be used for assessing allelopathic interactions. The study of the molecular mechanism of growth inhibition by these compounds is the prospect.

\section{AUTHOR CONTRIBUTIONS}

All authors made substantial contributions to conception and design, acquisition of data, or analysis and interpretation of data; took part in drafting the article or revising it critically for important intellectual content; agreed to submit to the current journal; gave final approval of the version to be published; and agree to be accountable for all aspects of the work. All the authors are eligible to be an author as per the international committee of medical journal editors (ICMJE) requirements/guidelines.

\section{FUNDING}

There is no funding to report.

\section{CONFLICTS OF INTEREST}

The authors report no financial or any other conflicts of interest in this work.

\section{ETHICAL APPROVALS}

This study does not involve experiments on animals or human subjects.

\section{PUBLISHER'S NOTE}

This journal remains neutral with regard to jurisdictional claims in published institutional affiliation.

\section{REFERENCES}

1. Babula P, Adam V, Kizek R, Sladký Z, Havel L. Naphthoquinones as allelochemical triggers of programmed cell death. Environ Exp Bot 2009;65:330-7.

2. Femina D, Lakshmipriya P, Subha S, Manonmani R. Allelopathic effects of weed (Tridax procumbens L.) extract on seed germination and seedling growth of some leguminous plants. Int Res J Pharm 2012;3:90-5.

3. Weston LA, Duke SO. Weed and crop allelopathy. CRC Crit Rev Plant Sci 2003;22:367-89.

4. Maharjan S, Shrestha BB, Jha PK. Allelopathic effects of aqueous extract of leaves of Parthenium hysterophorus L. on seed germination and seedling growth of some cultivated and wild herbaceous species. Sci World J 2007;5:33-9.

5. Wang P, Liang W, Kong C, Jiang Y, Zhang M, Zhang C. Chemical mechanism of exotic weed invasion. Ying Yong Sheng Tai Xue Bao 2004;15:707-11.

6. Hierro JL, Callaway RM. Allelopathy and exotic plant invasion. Plant Soil 2003;256:29-39.

7. Mallik AU. Can Kalmia angustifolia interference to black spruce (Picea mariana) be explained by allelopathy? For Ecol Manag 2002;160:75-84.

8. Majeed AB, Chaudhry Z, Muhammad Z. Allelopathic assessment of fresh aqueous extracts of Chenopodium album L. for growth and yield of wheat (Triticum aestivum L.). Pak J Bot 2012;44:165-7. 
9. Pan L, Li XZ, Yan ZQ, Guo HR, Qin B. Phytotoxicity of umbelliferone and its analogs: Structure-activity relationships and action mechanisms. Plant Physiol Biochem 2015;97:272-7.

10. Scavo A, Restuccia A, Mauromicale G. Allelopathy: Principles and basic aspects for agroecosystem control. J Sustain Rev 2018;28: 47-101.

11. Macías FA, Galindo JC, Massanet GM. Potential allelopathic activity of several sesquiterpene lactone models. Phytochem Rev 1992;31:1969-77.

12. Scavo A, Restuccia A, Abbate C, Mauromicale G. Seeming field allelopathic activity of Cynara cardunculus L. reduces the soil weed seed bank. Agron Sustain Dev 2019;39:41.

13. Dao TH. Sorption and mineralisation of plant phenolic acids in soil. ACS Symp Ser Am Chem Soc 1987;330:358-70.

14. Rizvi SJ (ed). Allelopathy: basic and applied aspects. ISBN 978-94011-2376-1 Springer e-Book 2012.

15. Blum U. Allelopathy: a soil system perspective.( in) Allelopathy. Manuel JR, Nuria P, Luís G ( eds). 2006; pp 299-340. Doi: 10.1007/14020-4280-9.

16. El-Amier YA, Abdullah TJ. Allelopathic effect of four wild species on germination and seedling growth of Echinocloa crus-galli (L.) P. Beauv. Int J Curr Adv Res 2014;2:287-94.

17. Khalid S, Ahmad T, Shad RA. Use of allelopathy in agriculture. Asian J Plant Sci 2002;1:292-7.

18. Lovett JV, Levitt JU, Duffield AM, Smith NG. Allelopathic potential of Datura stramonium L. (Thorn-apple). Weed Res 1981;21:165-70.

19. Razavi SM. Plant coumarins as allelopathic agents. Int J Biol Chem 2011;5:86-90.

20. Weber E, Sun SG, Li B. Invasive alien plants in China: Diversity and ecological insights. Biol Invasions 2008;10:1411-29.

21. Azizan KA, Ibrahim S, Ghani NH, Nawawi MF. LC-MS based metabolomics analysis to identify potential allelochemicals in Wedelia trilobata. Rec Nat Prod 2016;10:788.

22. International Union for Conservation of Nature. IUCN Species Survival Commission, International Union for Conservation of Nature, and Natural Resources. Species Survival Commission. IUCN Red List Categories and Criteria. Gland, Switzerland: International Union for Conservation of Nature; 2001.

23. Zhang Y, Liu M, Ling T, Wei X. Allelopathic sesquiterpene lactones from $\{\backslash \mathrm{s} 1$ Wedelia trilobata $\}$. J Trop Subtrop Bot 2004;12:533-7.

24. Golisz A, Lata B, Gawronski SW, Fujii Y. Specific and total activities of the allelochemicals identified in buckwheat. Weed Biol Manag 2007:7:164-71.

25. Ma HJ, Zhang JH, Xia XD, Xu MH, Ning J, Li JH. Design, synthesis and herbicidal activities of novel 4- (1 H-pyrazol-1yl) -6-(alkynyloxy)-pyrimidine derivatives as potential pigment biosynthesis inhibitors. Pest Manag Sci 2014;70:946-52.

26. Patel B, Achariya B, Bupripata NP. Allelopathic effects of Eucalyptus leaves on seed germination seedling growth of winter wheat. Proceedings of Indian Society of Allelopathy 2002;115-9.

27. Anaya AL. Allelopathy as a tool in the management of biotic resources in agroecosystems. CRC Crit Rev Plant Sci 1999;18:697-739.

28. Bewley JD, Bradford KJ, Hilhorst HW, Nonogaki H. Germination. In: Seeds. New York: Springer; 2013. p. 133-81.

29. Tanveer A, Safdar ME, Tariq MA, Yasin M, Noorka IR. Allelopathic inhibition of germination and seedling vigor of some selected crops by Achyranthes aspera L. Herbologia 2014;14:35-46.

30. Al-Shatti AH, Redha A, Suleman P, Al-Hasan R. The allelopathic potential of Conocarpus lancifolius (Engl.) leaves on Dicot (Vigna sinensis L.), Monocot (Zea mays L.) and soil-borne pathogenic fungi. Am J Plant Sci 2014;5:2889-903.

31. Turk MA, Tawaha AM. Allelopathic effect of black mustard (Brassica nigra L.) on germination and growth of wild oat (Avena fatua L.). Crop Prot 2003;22:673-7.
32. Fikreyesus S, Kebebew Z, Nebiyu A, Zeleke N, Bogale S. Allelopathic effects of Eucalyptus camaldulensis Dehnh. on germination and growth of tomato. Am Eur J Agric Environ Sci 2011;11:600-8.

33. Bora IP, Singh J, Borthakur R, Bora E. Allelopathic effect of leaf extracts of Acacia auriculiformis on seed germination of some agricultural crops. Ann For Sci 1999;7:143-6.

34. Chung IM, Miller DA. Natural herbicide potential of alfalfa residue on selected weed species. Agron J 1995;87:920-5.

35. Conway WC, Smith LM, Bergan JF. Potential allelopathic interference by the exotic Chinese tallow tree (Sapium sebiferum). Am Midl Nat 2002;148:43-53.

36. Oyun MB. Allelopathic potentialities of Gliricidia sepium and Acacia auriculiformis on the germination and seedling vigour of maise (Zea mays L.). Am J Agric Biol Sci 2006;1:44-7.

37. Aliotta G, Cafiero G, De Feo V, Sacchi R. Potential allelochemicals from Ruta graveolens L. and their action on radish seeds. J Chem Ecol 1994;20:2761-75.

38. Evangeline VR, Prakash EJ, Samuel AS, Jayakumar M. Allelopathic potential of Tectona grandis $\mathrm{L}$. on the germination and seedling growth of Vigna mungo (L.) Hepper. Pak J Weed Sci Res 2012;18:65-70.

39. Nie CR, Li HS, Huang JH, Cheng LQ, Hong MQ. Studies of the allelopathic effects of Wedelia chinensismerr. on rice. Zuo Wu Xue Bao 2002;30:942-6.

40. Omezine A, Skhiri-Harzallah F. Resumption and growth of Cynodon dactylon rhizome fragments. Pak J Weed Sci Res 2011;17:215-27.

41. Eyini M, Maheswari AU, Chandra T, Jayakumar M. Allelopathic effects of leguminous plants leaf extracts on some weeds and corn. Allelopathy J 1996;3:85-8.

42. Mnafgui K, Hamden K, Ben Salah H, Kchaou M, Nasri M, Slama S, et al. Inhibitory activities of Zygophyllum album: A natural weightlowering plant on key enzymes in high-fat diet-fed rats. Evid Based Complement Altern Med 2012;2012:620384.

43. Schulze E, Kirschner M. Microtubule dynamics in interphase cells. J Cell Biol 1986;102:1020-31.

44. İlbaş Aİ, Gönen U, Yilmaz S, Dadandi MY. Cytotoxicity of Aloe vera gel extracts on Allium cepa root tip cells. Turk J Bot 2012;36:263-8.

45. Anese S, Gualtieri SC, Grisi PU, Jatobá LD, Arduin M. Phytotoxic potential of Drimys brasiliensis Miers for use in weed control. Acta Sci Agron 2015;37:505-16.

46. Chaudhuri A, Ray S. Determination of effective allelopathic (inhibitory) extract fractions of Ampelocissus latifolia (Roxb.) Plant leaf. Eur J Exp Biol 2015;5:1-7.

47. Muir AD, Majak W. Allelopathic potential of diffuse knapweed (Centaurea diffusa) extracts. Can J Plant Sci 1983;63:989-96.

48. Jana A, Biswas SM. Lactam nonanic acid, a new substance from Cleome viscosa with allelopathic and antimicrobial properties. J Biosci 2011;36:27-35.

49. Lobón NC, de la Cruz IF, Gallego JC. Autotoxicity of diterpenes present in leaves of Cistus ladanifer L. J Plant Stud 2019;8:27.

50. Bai Z, Huang Y, Huang J. Allelopathic effects of artemisinin on seed germination and seedling growth of vegetables. Sheng Tai Xue Bao 2013;23:29.

51. Takemura T, Kamo T, Sakuno E, Hiradate S, Fujii Y. Discovery of coumarin as the predominant allelochemical in Gliricidia sepium. $\mathrm{J}$ Trop Sci 2013;25:268-72.

52. López-Pacheco IY, Salinas-Salazar C, Silva-Núñez A, RodasZuluaga LI, Donoso-Quezada J, Ayala-Mar S, Parra-Saldívar R. Removal and biotransformation of 4-nonylphenol by Arthrospira maxima and Chlorella vulgaris consortium. Environ Res 2019;179:108848.

53. Au TK, Chick WS, Leung PC. The biology of opiobolins. Life Sci 2000;67:733-42.

54. Purvis CE, Jessop RS, Lovett JV. Selective regulation of germination and growth of annual weeds by crop residues. Weed Res 1985;25:415-21.

55. Sinha NK, Singh SJ. Allelopathic effects of Xanthium strumarium on 
Parthenium hysterophorus. Indian J Plant Physiol 2004;9:313-5.

56. Swain D, Pandey P, Paroha S, Singh M, Yaduraju NT. Effects of Physalis minima on Parthenium hysterophorus. Allelopathy J 2005;15:275-83.

57. Tantiado RG, Saylo MC. Allelopathic potential of selected grasses (Family Poaceae) on the germination of Lettuce seeds (Lactuca sativa). Int J Biotechnol 2012;4:27-34.

58. Kaur H, Kaur R, Kaur S, Baldwin IT. Taking ecological function seriously: Soil microbial communities can obviate allelopathic effects of released metabolites. PLoS One 2009;4:e4700.

59. Weidenhamer JD, Boes PD, Wilcox DS. Solid-phase root zone extraction (SPRE): A new methodology for measurement of allelochemical dynamics in soil. Plant Soil 2009;322:177-86.
60. Phlomina NS, Srivasuki KP. Allelopathic studies on agroforestry species: Effect of leaf leachates on seed germination of crop plants. Indian J For 1996;19:45-53.

61. Sidhu DS, Hans AS. Preliminary studies on the effect of Eucalyptus leaflitter on accumulation of biomass in wheat. J Trop Sci 1988;4:328-33.

How to cite this article:

Shahena S, Rajan M, Chandran V, Mathew L. Allelopathic effect of Wedelia trilobata L., on the germination and growth of Cicer arietinum, Vigna

unguiculata, and Vigna radiata seedlings. J App Biol Biotech. 2021;9(2):93-114. DOI: 10.7324/JABB.2021.9209 


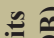

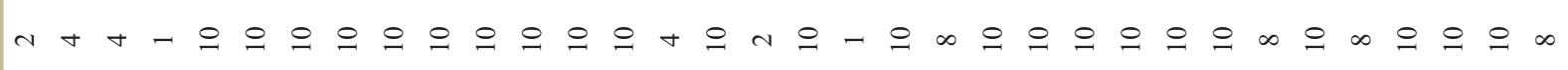

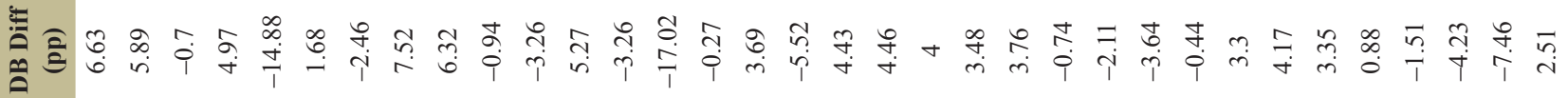

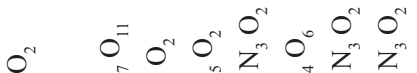

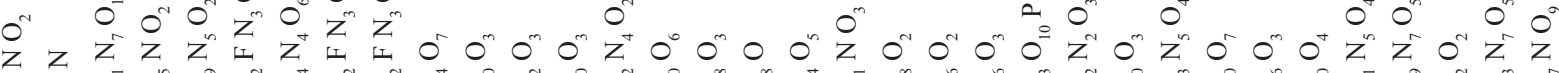

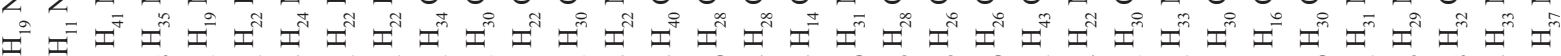

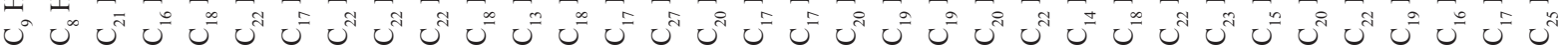

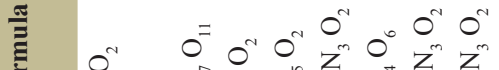

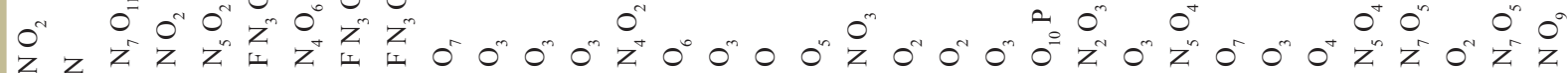

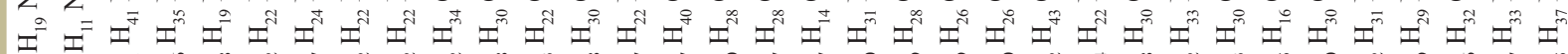

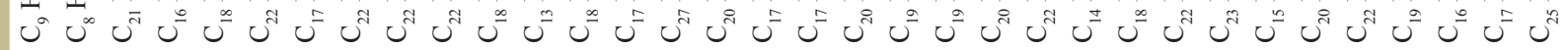

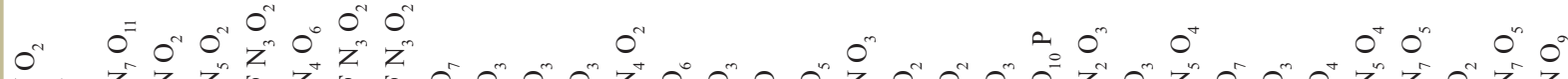

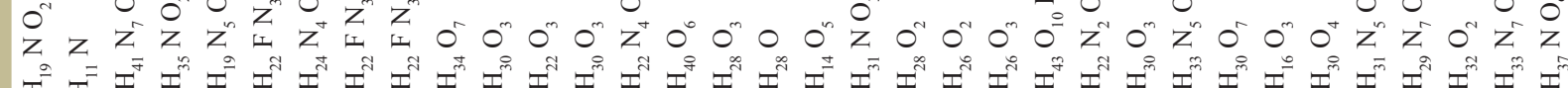

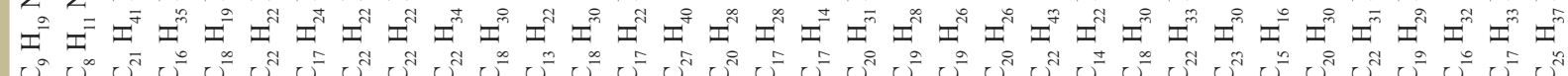

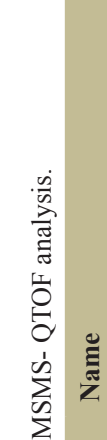

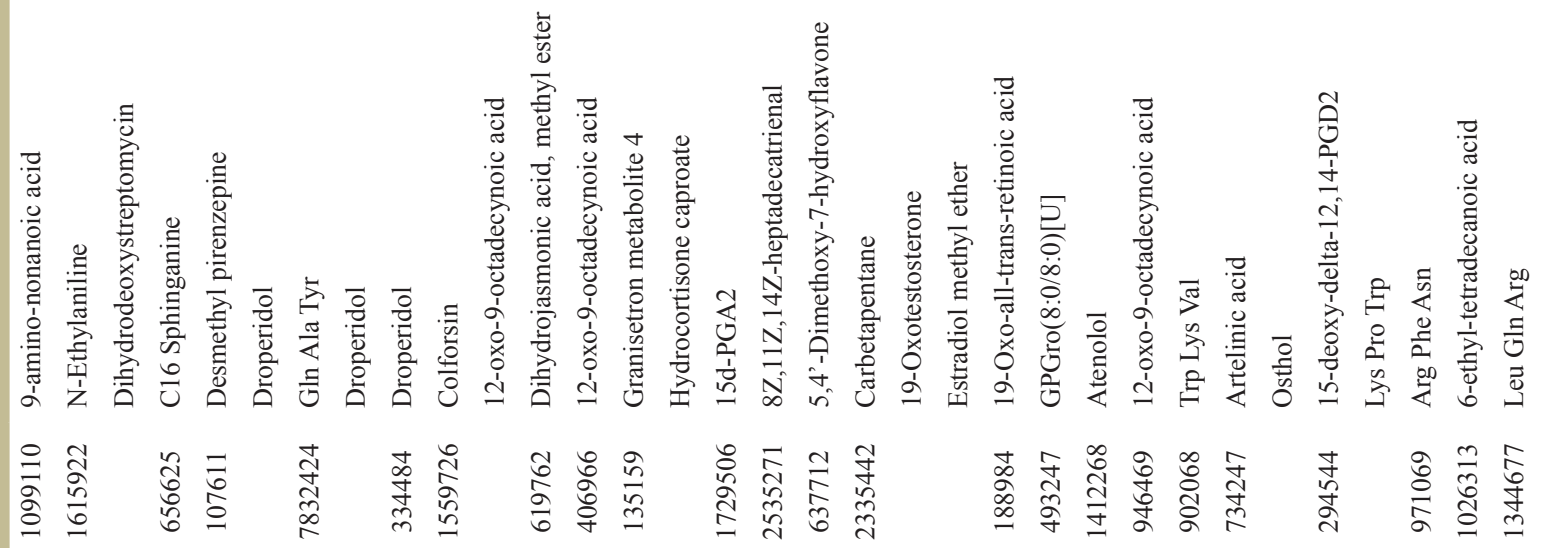

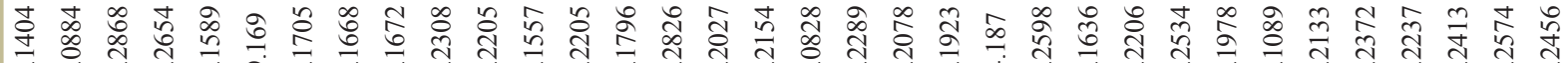

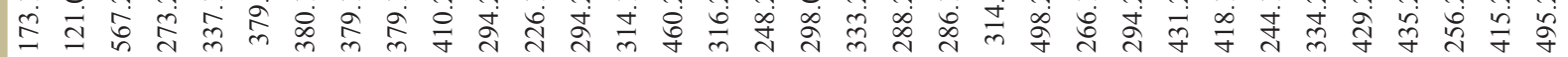

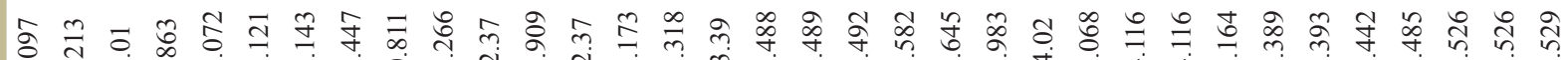




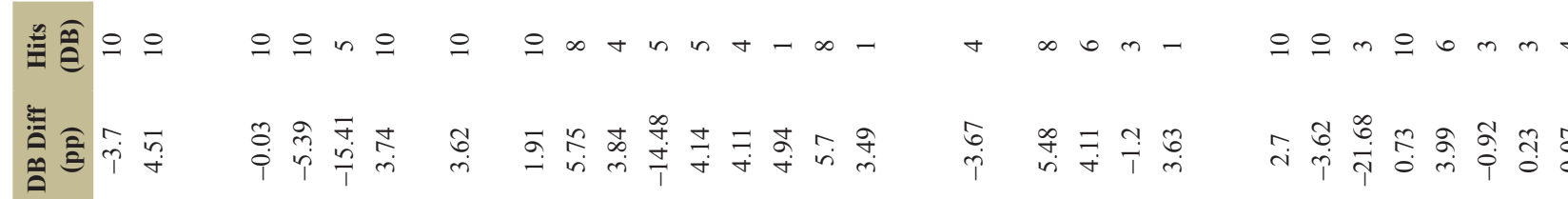

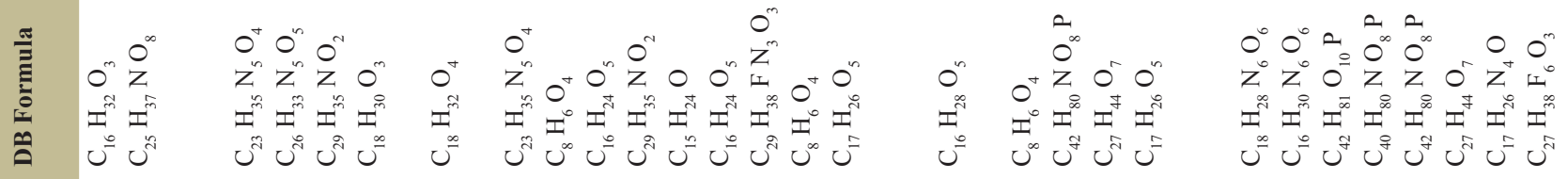

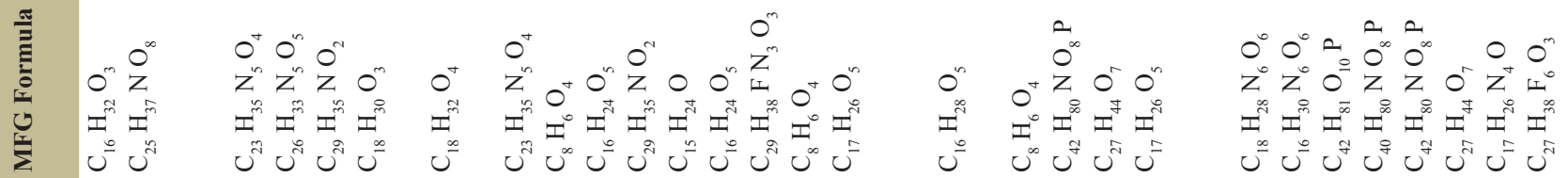

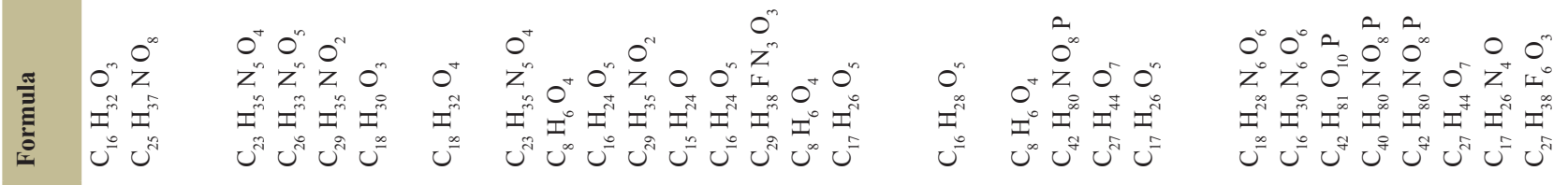
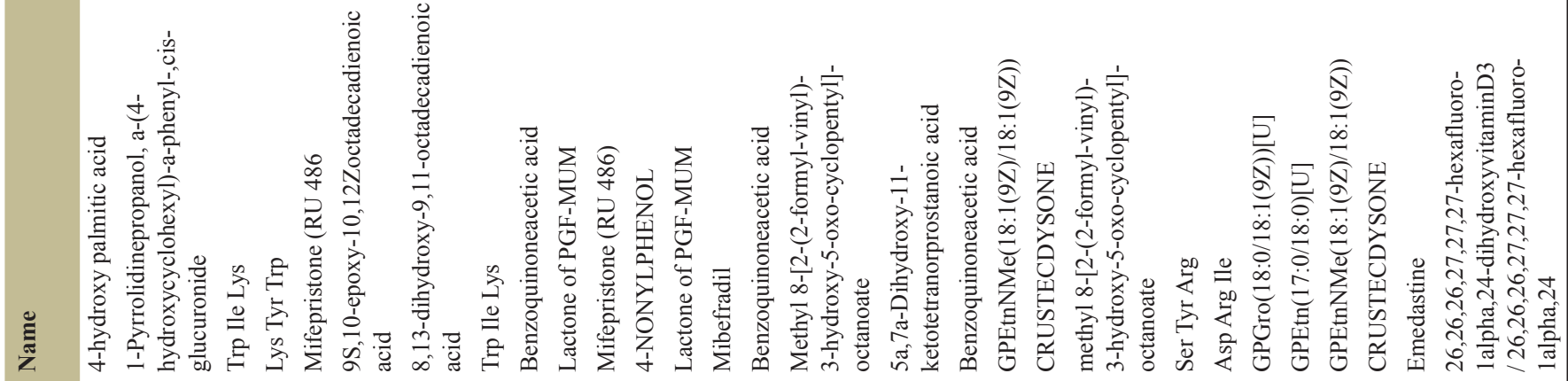

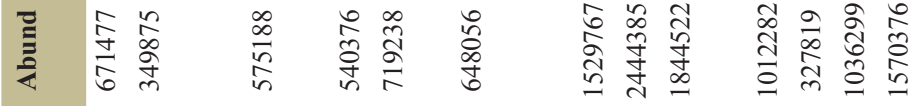

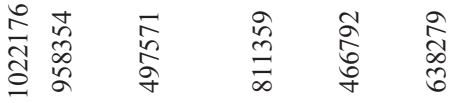

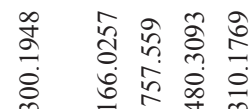

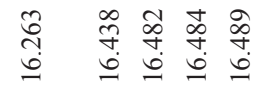

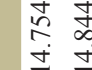

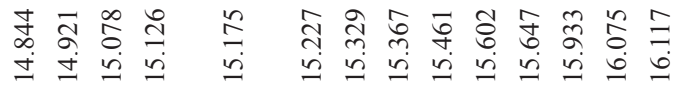
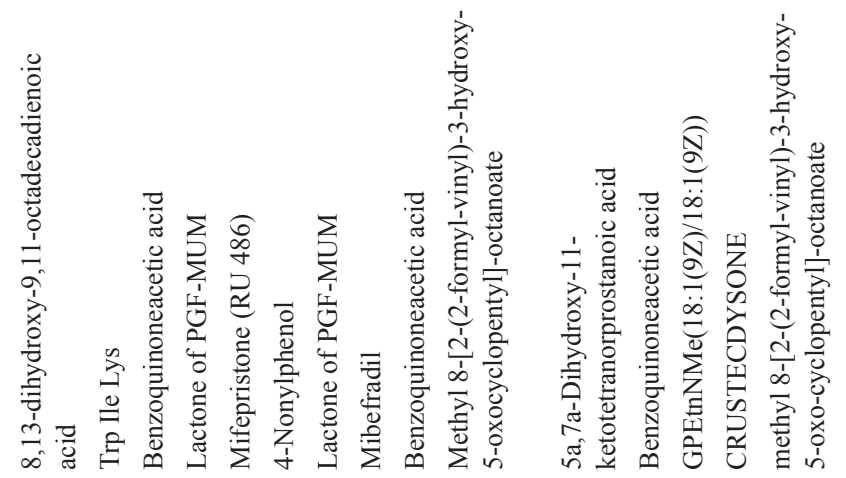

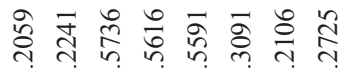

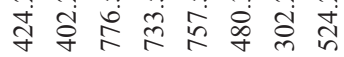

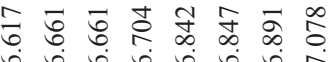

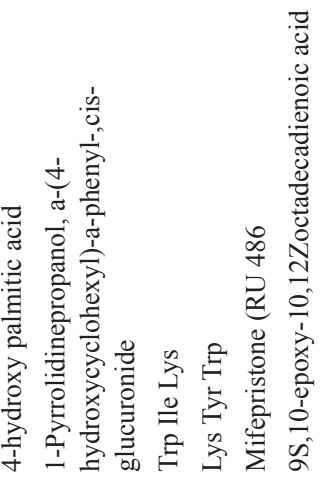
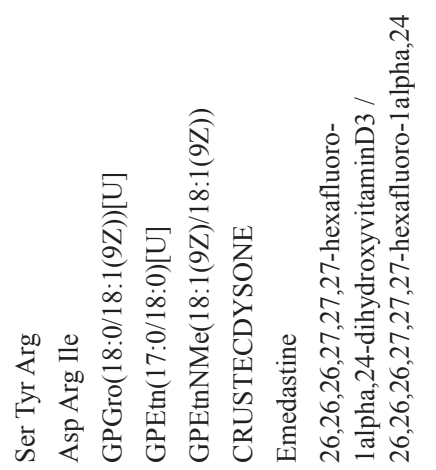


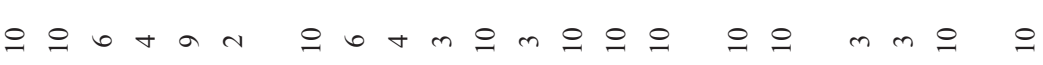

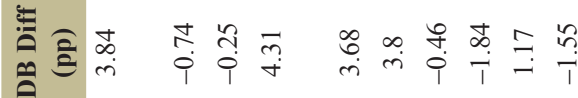

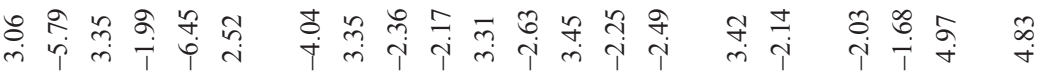

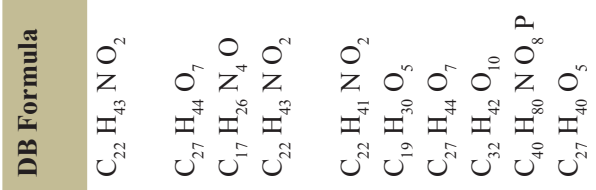

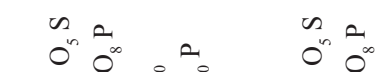

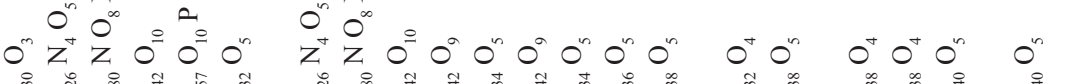

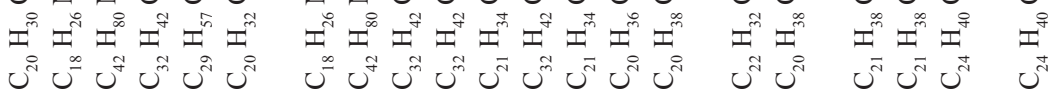

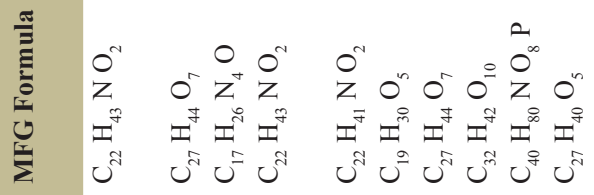

$n^{n} \infty_{\infty}=n^{n} \infty_{\infty}^{\infty}$

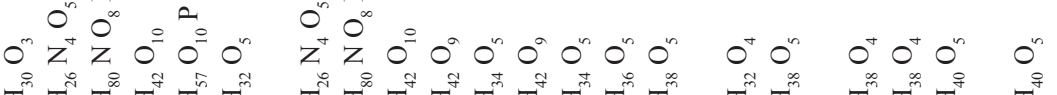

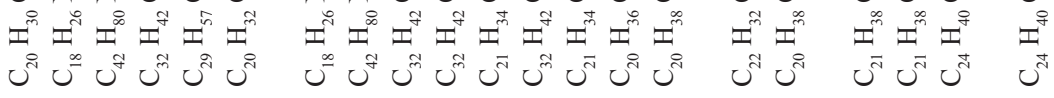

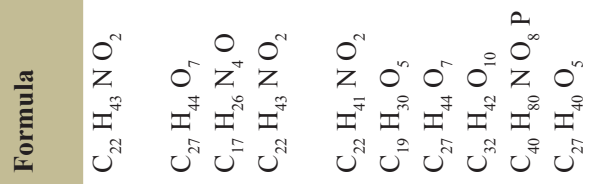

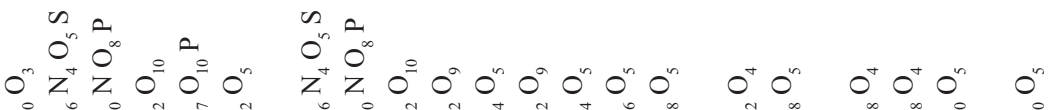

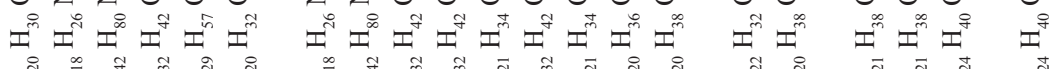

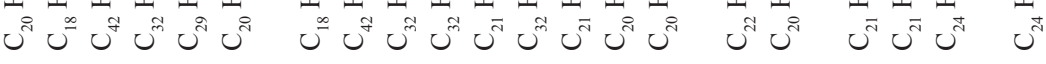

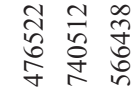

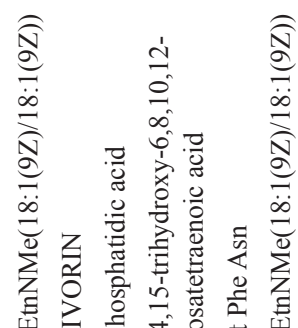

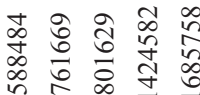
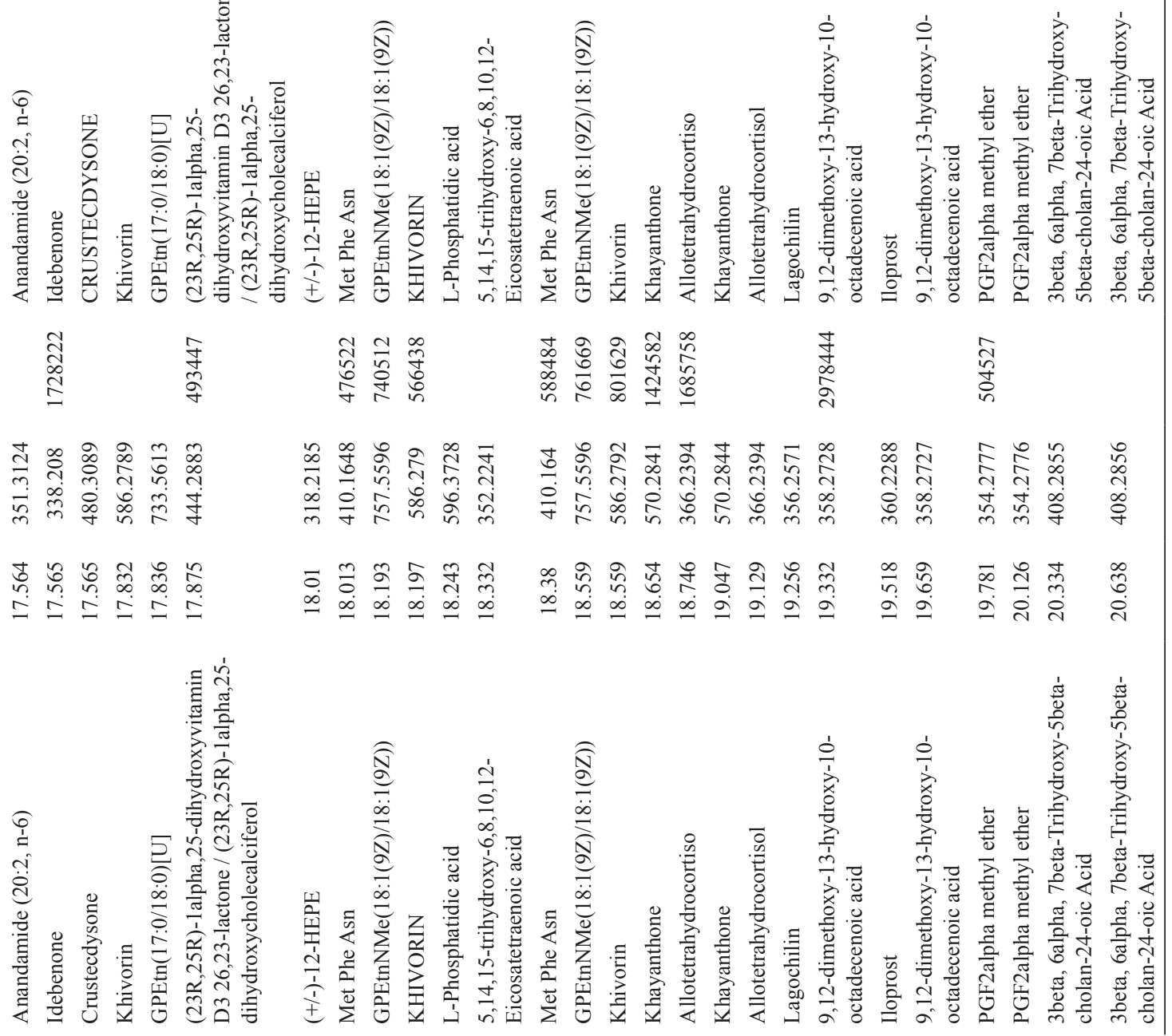


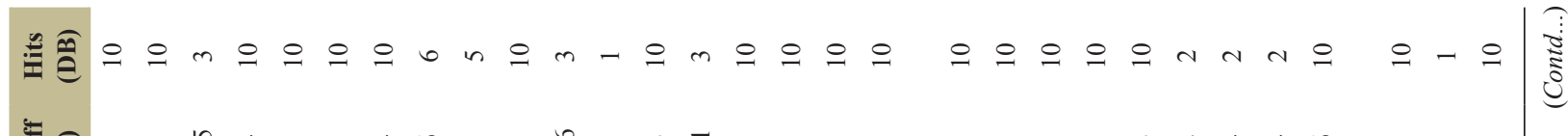

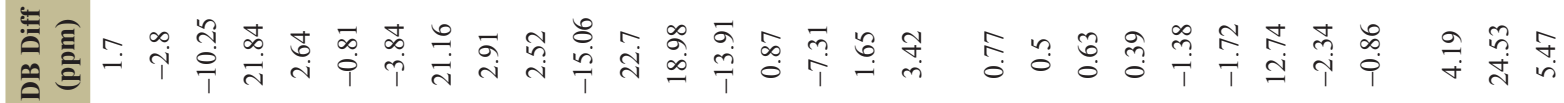

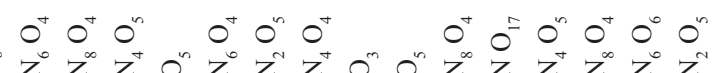
$0^{\infty} z^{\infty} z^{\infty} z^{+} O^{n} z^{\infty} z^{n} z^{+} O^{n} O^{n} z^{\infty} z^{\infty} z^{+} z^{\infty} z^{\infty} z^{n} O^{\infty} 0^{n}$

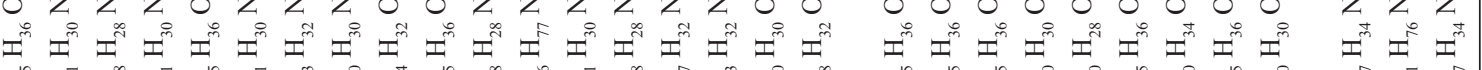

$0^{n} 0^{n} 0^{\infty} 0^{n} 0^{n} 0^{+} 0^{n} 0^{+} 0^{n}$

$0^{n} 0^{n} 0^{n}$

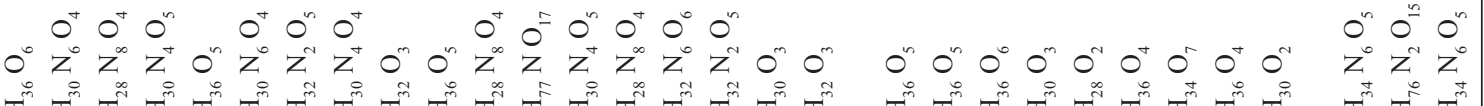

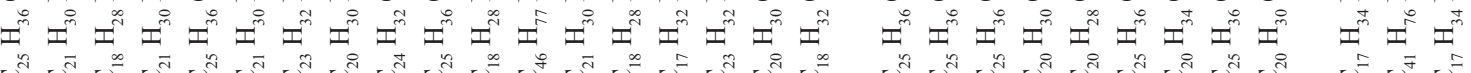

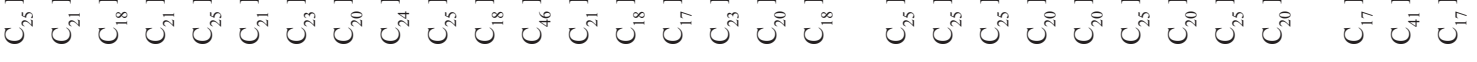

$0^{+} O^{+} O^{n} \quad 0^{+} O^{n} O^{+} \quad 0^{+} O^{n} O^{n} O^{+} 0^{\infty} 0^{n}$

$0^{0} z^{\infty} z^{\infty} z^{+} O^{n} z^{\infty} z^{n} z^{+} 0^{n} O^{n} z^{\infty} z^{\infty} z^{+} z^{\infty} z^{\infty} z^{n} O^{n} O^{m}$

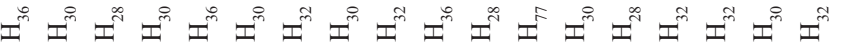

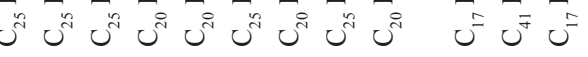

$0^{\text {nn }} 0^{\text {nn }} 0^{0} 0^{n} 0^{n} 0^{+} 0^{n} 0^{+} 0^{n}$

$0^{n} 0^{n} 0^{n}$

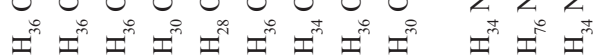

กินี

\section{- 0 o 0 个}

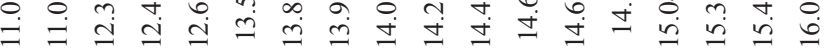




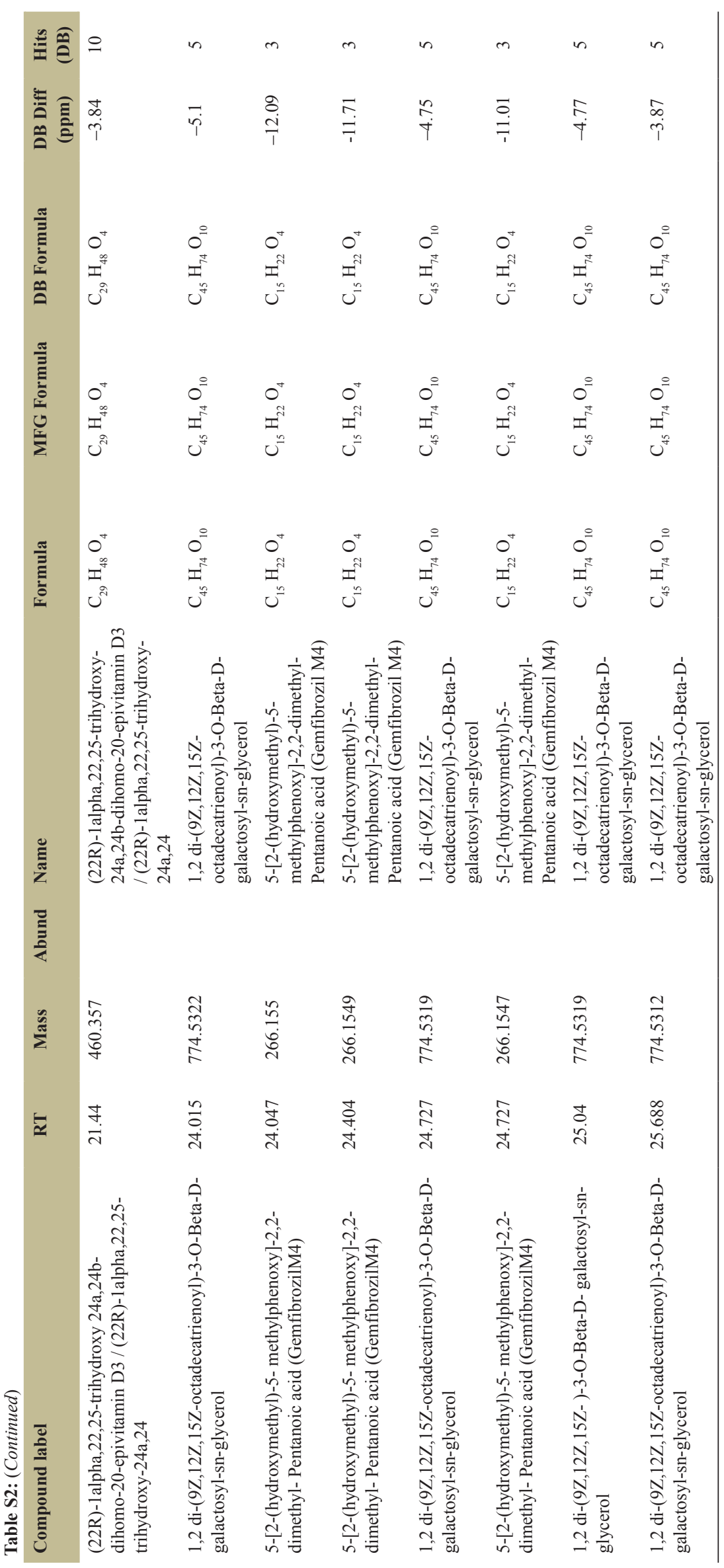


Spectroscopic data of allelopathic compounds obtained by HRLCMS- MSMS- QTOF analysis

1. 9-amino-nonanoic acid

\begin{tabular}{|l|l|l|l|l|l|}
\hline Compound Label & Name & $\mathrm{m} / \mathrm{z}$ & $\mathrm{RT}$ & Algorithm & Mass \\
\hline 9-amino-nonanoic acid & 9 -amino-nonanoic acid & 156.137 & 1.097 & Auto MS/MS & 173.1404 \\
\hline
\end{tabular}

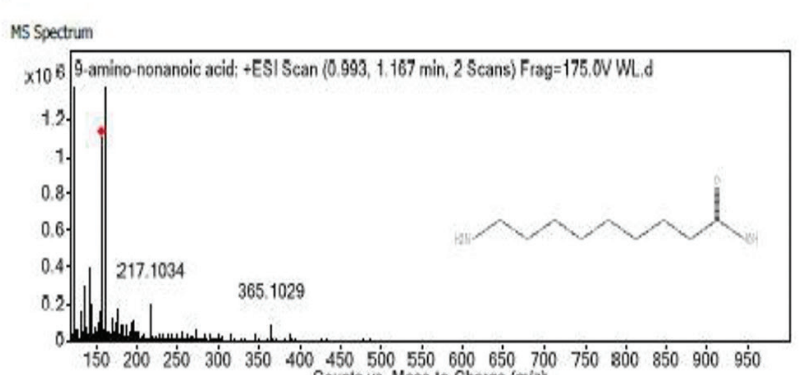

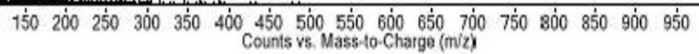

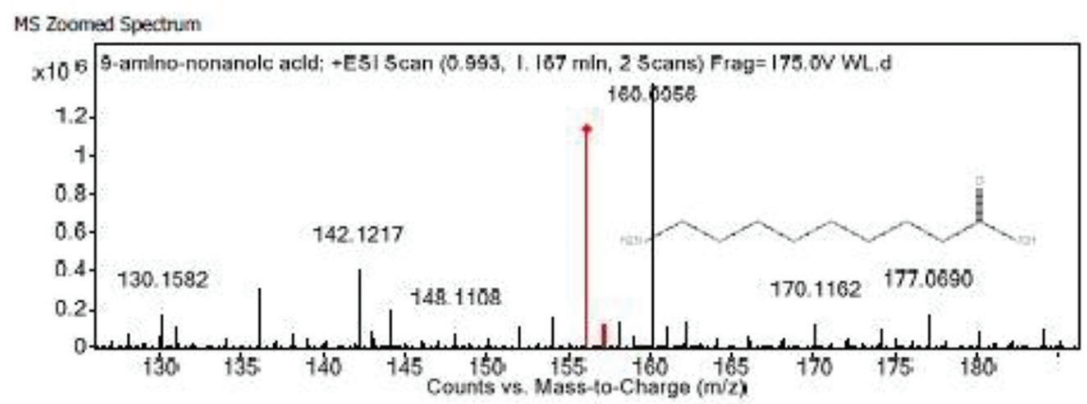

\begin{tabular}{|c|c|c|c|c|c|c|}
\hline$m / z$ & Calc $\mathrm{m} / \mathbf{z}$ & Diff(ppm) & $x$ & Abund & Formula & Ion \\
\hline 122.0954 & & & 1 & 1374728.63 & & \\
\hline 136.1112 & & & 1 & 296522.03 & & \\
\hline 142.1217 & & & 1 & 397338.38 & & \\
\hline 144.1007 & & & & 191334.19 & & \\
\hline 156.137 & 156.1383 & 8.25 & 1 & 1099110.38 & $\mathrm{C} 9 \mathrm{H} 19 \mathrm{~N} \mathrm{O2}$ & $(\mathrm{M}+\mathrm{H})+\left[-\mathrm{H}_{2} \mathrm{O}\right]$ \\
\hline 157.1406 & 157.1415 & 5.83 & 1 & 103340,01 & $\mathrm{C} 9 \mathrm{H} 19 \mathrm{~N} \mathrm{O2}$ & $(\mathrm{M}+\mathrm{H})+\left[-\mathrm{H}_{2} \mathrm{O}\right]$ \\
\hline 158.1495 & 158.144 & -34.78 & 1 & 18695.27 & $\mathrm{C} 9 \mathrm{H} 19 \mathrm{~N} \mathrm{O} 2$ & $(\mathrm{M}+\mathrm{H})+\left[-\mathrm{H}_{2} \mathrm{O}\right]$ \\
\hline 160.0956 & & & 1 & 1371763.38 & & \\
\hline 160.1306 & & & & 173236.14 & & \\
\hline 217.1034 & & & & 194632.09 & & \\
\hline
\end{tabular}

MSMS Spectrum

$\times 10^{2}$ 9-amino-nonanoic acid: +ESI Product lon $(1.016,1.179$ min, 2 Scans) Frag=175. 0V CID@10.0 (1..

6. 156.1003

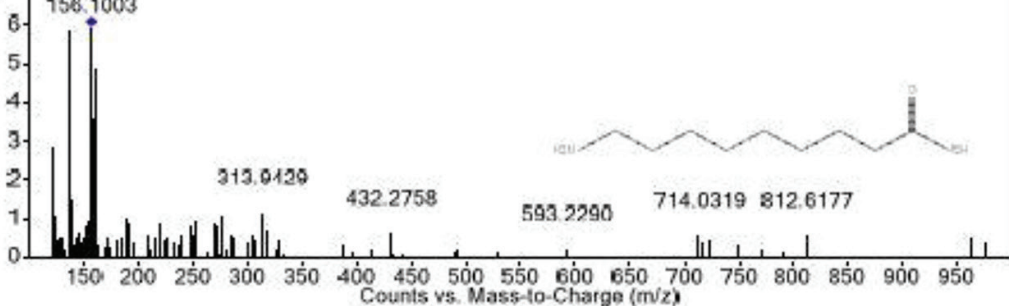

MS/MS Spectum Peak List

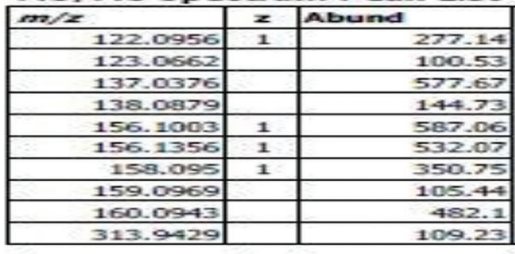

Compoumd Structure

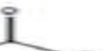


2. Colforsin

\begin{tabular}{|l|l|l|l|l|l|}
\hline Compound Label & Name & $m / z$ & RT & Algorithm & Mass \\
\hline COLFORSIN & COLFORSIN & 415.2094 & 12.266 & Auto MS/MS & 410.2308 \\
\hline
\end{tabular}

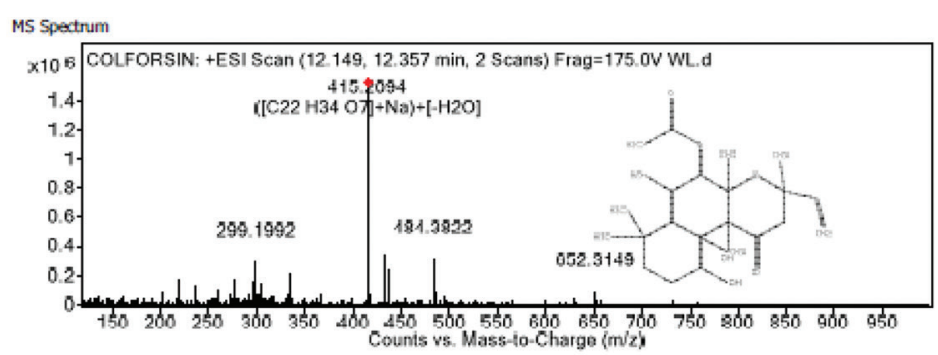

\section{MS Zoomed Spectrum}
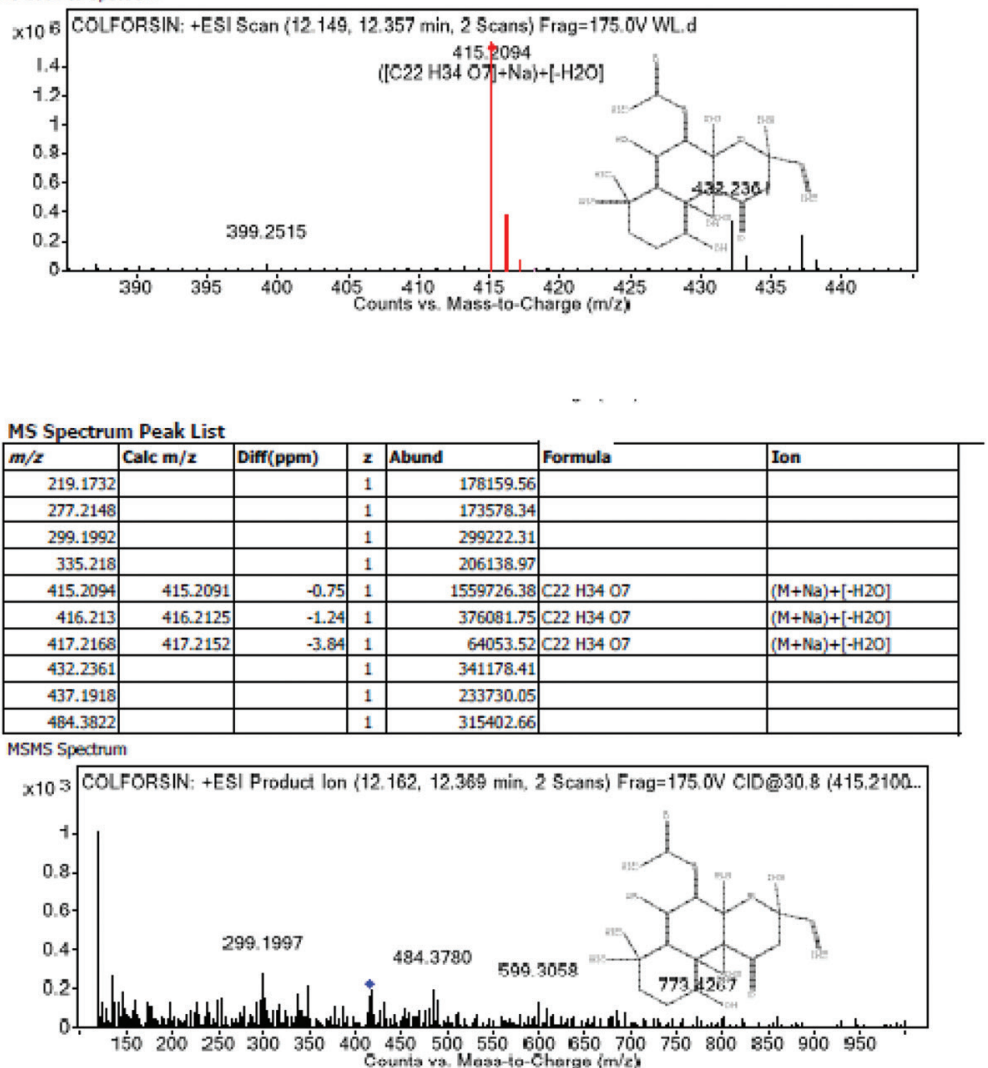

\begin{tabular}{|c|c|c|c|c|c|}
\hline \multicolumn{4}{|c|}{ MS/MS Spectrum Peak List } & \multirow[b]{2}{*}{ Formula } & \multirow[b]{2}{*}{ Ion } \\
\hline \begin{tabular}{|l|l}
$m / z$ & $c$
\end{tabular} & Cale $\mathrm{m} / \mathbf{z}$ & Diff (ppm) & Abund & & \\
\hline 120.0878 & & & 1011.69 & & \\
\hline 133.0636 & & & 259.14 & & \\
\hline \begin{tabular}{|l|l|}
135.1159 \\
\end{tabular} & & & 153.92 & & \\
\hline 145.1003 & & & 178.56 & & \\
\hline 299.1997 & & & 272.11 & & \\
\hline 336.2578 & & & 168 & & \\
\hline 349.2001 & & & 202.72 & & \\
\hline 415.214 & & & 159.45 & & \\
\hline 416.213 & 416.2125 & -1.06 & 190.51 & $\mathrm{C} 22 \mathrm{H} 3407$ & $(\mathrm{M}+\mathrm{Na})+[-\mathrm{H} 2 \mathrm{O}]$ \\
\hline 484.378 & & & 195.63 & & \\
\hline
\end{tabular}

Compound Structure

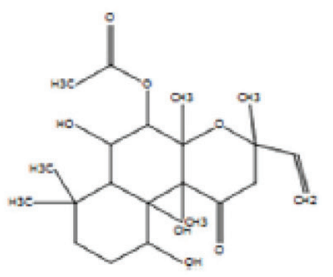


3. Artelinic acid

\begin{tabular}{|l|l|l|l|l|l|}
\hline Compound Label & Name & $m / z$ & $R T$ & Algorithm & Mass \\
\hline Artelinic acid & Artelinic acid & 441.186 & 14.164 & Auto MS/MS & 418.1978 \\
\hline
\end{tabular}

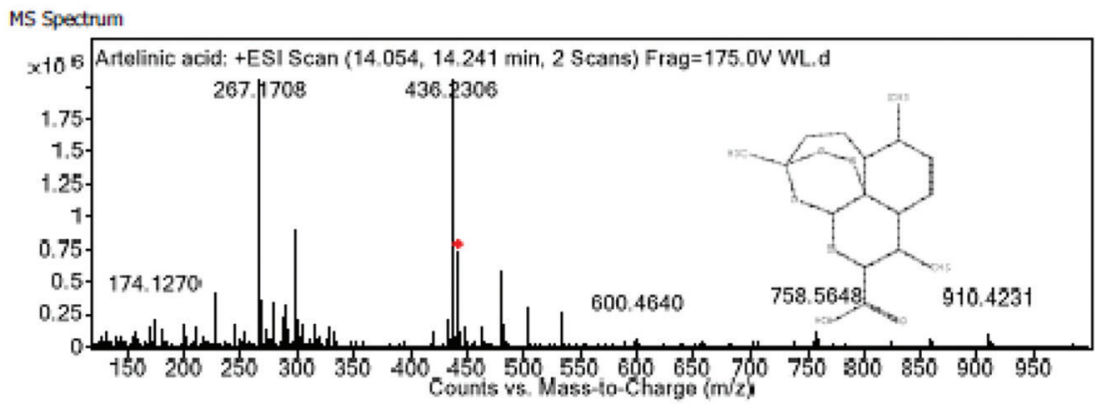

MS Zoomed Spectrum

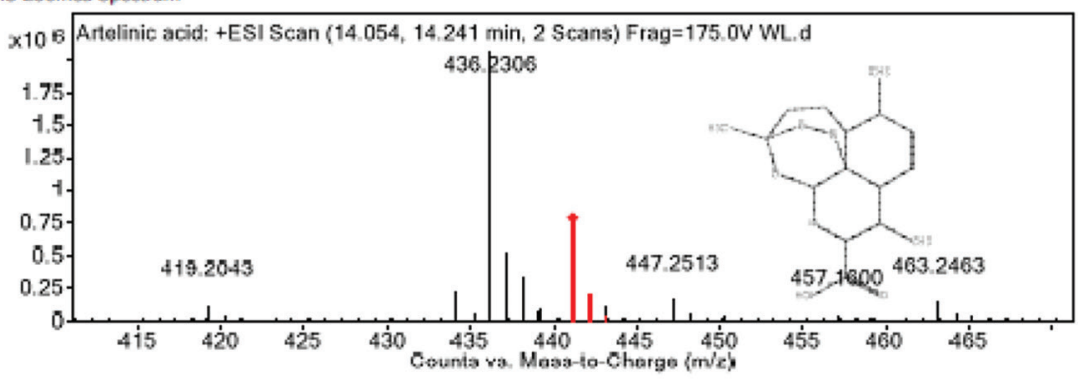

\begin{tabular}{|c|c|c|c|c|c|c|}
\hline \multicolumn{5}{|c|}{ MS Spectrum Peak List } & \multirow[b]{2}{*}{ Formula } & \\
\hline$m / z$ & Calc $\mathrm{m} / \mathbf{z}$ & Diff(ppm) & $z$ & Abund & & Ion \\
\hline 227.1054 & & & 1 & 400567.13 & & \\
\hline 267.1708 & & & 1 & 2555037 & & \\
\hline 299.1991 & & & 1 & 895134.5 & & \\
\hline 436.2306 & & & 1 & 2052762.5 & & \\
\hline 437.2344 & & & 1 & 517373.44 & & \\
\hline 441.186 & 441.1884 & 5.48 & 1 & 734247.06 & $\mathrm{C} 23 \mathrm{H3O} 07$ & $(\mathrm{M}+\mathrm{Na})+$ \\
\hline 442.1897 & 442.1918 & 4.72 & 1 & 178628.27 & $\mathrm{C2} 3 \mathrm{H} 3 \mathrm{O} 07$ & $(\mathrm{M}+\mathrm{Na})+$ \\
\hline 443.2 & 443.1944 & -12.66 & 1 & 101134.7 & $\mathrm{C} 23 \mathrm{H} 3 \mathrm{OO} 07$ & $(\mathrm{M}+\mathrm{Na})+$ \\
\hline 444.2039 & 444.197 & -15.36 & 1 & 22996.32 & $\mathrm{C23} \mathrm{H} 30 \mathrm{O} 07$ & $(\mathrm{M}+\mathrm{Na})+$ \\
\hline 481.2562 & & & 1 & 579277.44 & & \\
\hline
\end{tabular}

MSMS Spectrum

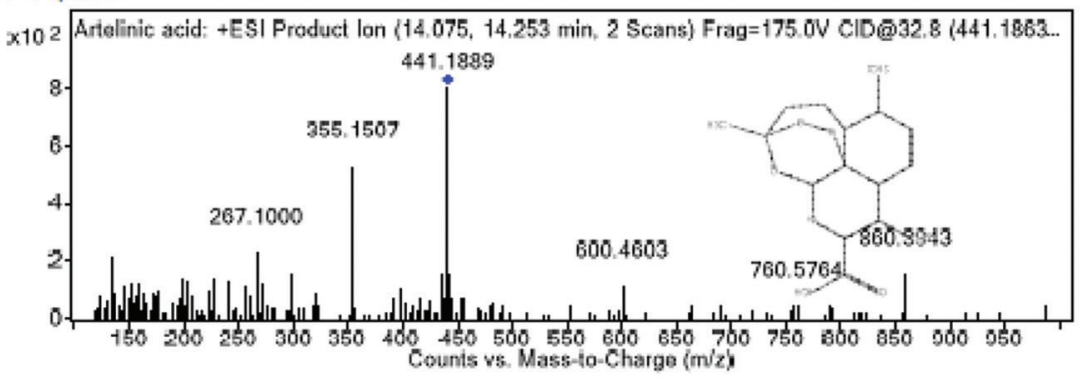

MS/MS Spectrum Peak List
\begin{tabular}{|r|r|r|}
\hline $\boldsymbol{m} / \boldsymbol{z}$ & $\mathbf{z}$ & Abund \\
\hline 133.0968 & & 206.17 \\
\hline 267.1 & & 226.46 \\
\hline 299.2017 & & 151.57 \\
\hline 353.1351 & & 310.12 \\
\hline 354.1373 & & 180.71 \\
\hline 355.1507 & 1 & 526.03 \\
\hline 436.2316 & 1 & 152.86 \\
\hline 441.1889 & 1 & $\mathbf{1}$ \\
\hline 442.1954 & 1 & 153.09 \\
\hline 860.3943 & & 152.25 \\
\hline
\end{tabular}

Compound Structure<smiles>CC(C)C1CC2OC3(C)CCC4C(O)CCC5C(O)C(C(C)C)C25OOC43O1</smiles> 
4. Osthol

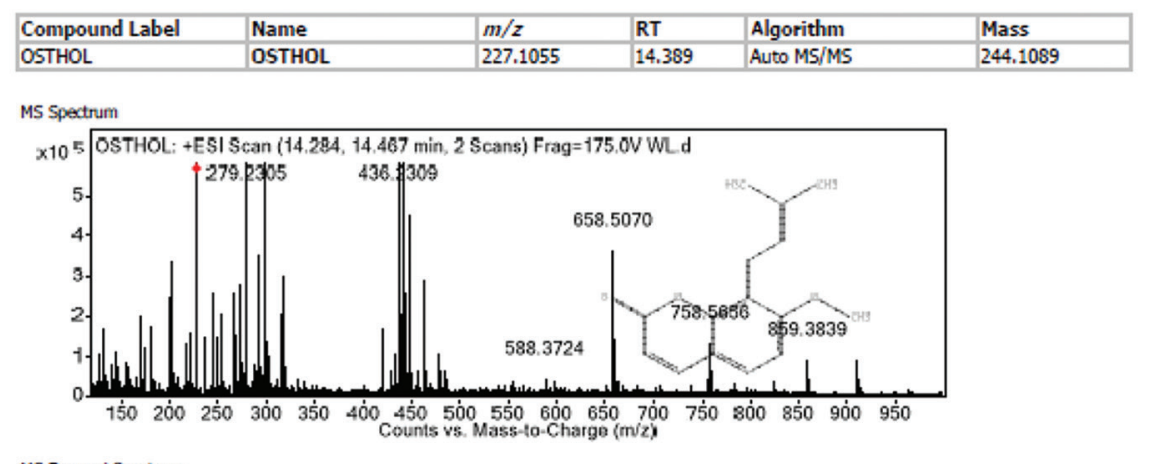

MS Zcomed Spectrum

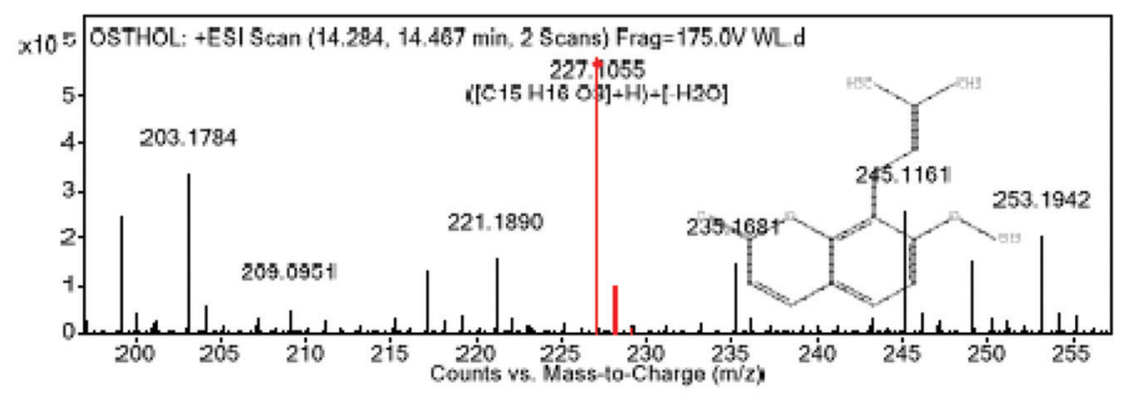

\begin{tabular}{|c|c|c|c|c|c|c|}
\hline$m / z$ & Calc m/z & Diff(ppm) & $z$ & Abund & Formula & Ion \\
\hline 227.1055 & 227.1067 & 5.12 & 1 & 579322.86 & $\mathrm{C} 15 \mathrm{H} 16 \mathrm{O} 3$ & $(\mathrm{M}+\mathrm{H})+\left[-\mathrm{H}_{2} \mathrm{O}\right]$ \\
\hline 228.1088 & 228.11 & 5.51 & 1 & 92507.27 & $\mathrm{C} 15 \mathrm{H} 16 \mathrm{O} 3$ & $(\mathrm{M}+\mathrm{H})+[-\mathrm{H} 2 \mathrm{O}]$ \\
\hline 229.1185 & 229.1128 & -24.91 & 1 & 15041.33 & $\mathrm{C} 15 \mathrm{H} 16 \mathrm{O} 3$ & $(\mathrm{M}+\mathrm{H})+[-\mathrm{H} 2 \mathrm{O}]$ \\
\hline 279.2305 & & & 1 & 928874.63 & & \\
\hline 299.1992 & & & 1 & 592827.13 & & \\
\hline 436.2309 & & & 1 & 2701717.75 & & \\
\hline 437.2341 & & & 1 & 697284.88 & & \\
\hline 438.2459 & & & 1 & 856833.63 & & \\
\hline 441.1861 & & & 1 & 1007912.5 & & \\
\hline 447.2511 & & & 1 & 447847.75 & & \\
\hline
\end{tabular}

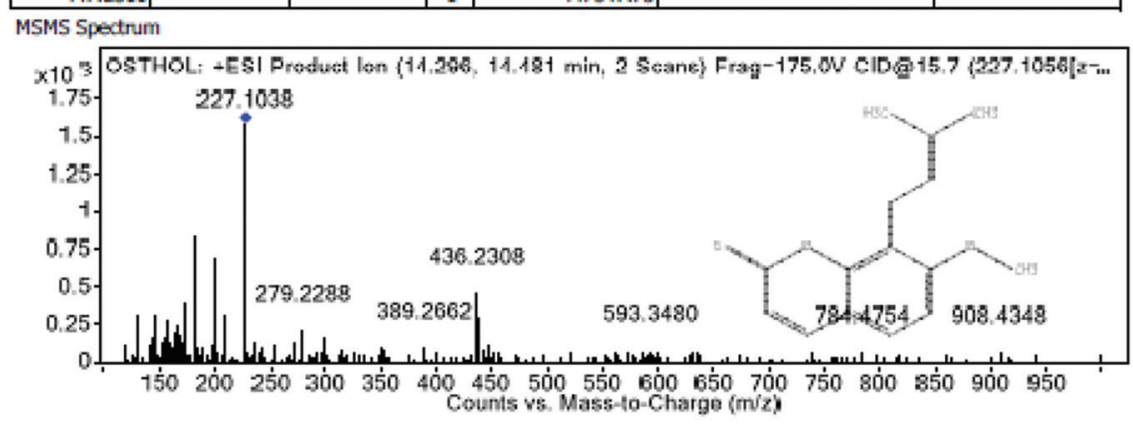

MS/MS Spectrum Peak List

\begin{tabular}{|r|r|r|}
\hline \multicolumn{1}{|l|}{$\boldsymbol{m} / \boldsymbol{z}$} & $\boldsymbol{z}$ & \multicolumn{1}{l|}{ Abund } \\
\hline 131.0462 & & 303.36 \\
\hline 145.101 & & 309.6 \\
\hline 171.114 & & 381.12 \\
\hline 181.0998 & 1 & 825.8 \\
\hline 199.1089 & & 676.33 \\
\hline 209.0915 & & 313.55 \\
\hline 227.1038 & 1 & 1565.73 \\
\hline 228.1082 & 1 & 314.81 \\
\hline 436.2308 & & 446.13 \\
\hline 437.2358 & & 293.83 \\
\hline
\end{tabular}

Compound Structure

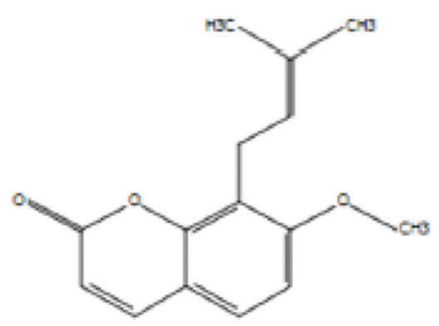


5. 4-Nonylphenol

\begin{tabular}{|l|l|l|l|l|l|}
\hline Compound Label & Name & $m / z$ & RT & Algorithm & Mass \\
\hline 4-NONYLPHENOL & 4-NONYLPHENOL & 203.1785 & 15.602 & Auto MS/MS & 220.1818 \\
\hline
\end{tabular}

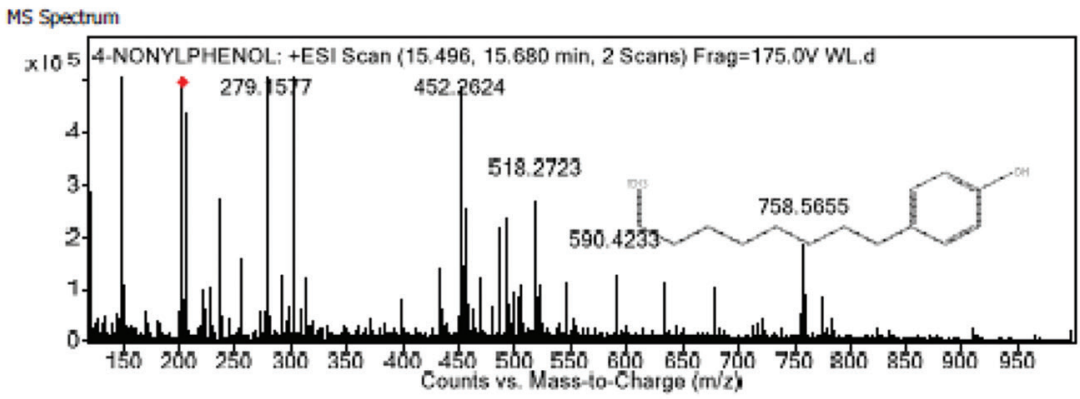

MS Zoomed Spectrum

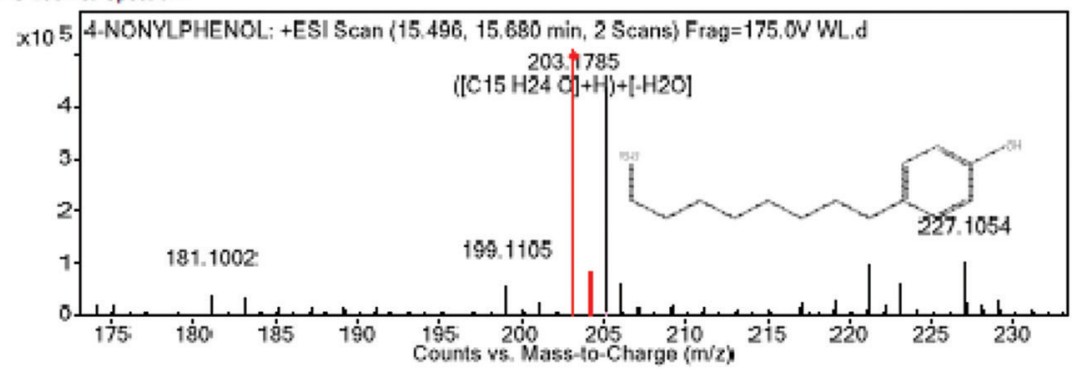

MS Spectrum Peak List
\begin{tabular}{|r|r|r|r|r|l|l|}
\hline $\boldsymbol{m} / \boldsymbol{z}$ & Calc $\mathbf{m} / \mathbf{z}$ & Diff(ppm) & $\mathbf{z}$ & Abund & Formula & Ion \\
\hline 121.0279 & & & & 287094 & & \\
\hline 149.0224 & & & 1 & 1310015.38 & & \\
\hline 203.1785 & 203.1794 & 4.43 & 1 & 508850.75 & $\mathrm{C} 15 \mathrm{H} 24 \mathrm{O}$ & $(\mathrm{M}+\mathrm{H})+[-\mathrm{H} 2 \mathrm{O}]$ \\
\hline 204.1818 & 204.1828 & 4.82 & 1 & 77120.12 & $\mathrm{C} 15 \mathrm{H} 24 \mathrm{O}$ & $(\mathrm{M}+\mathrm{H})+[-\mathrm{H} 2 \mathrm{O}]$ \\
\hline 205.0948 & & & 1 & 434300.34 & & \\
\hline 237.1838 & & & 1 & 269290.88 & & \\
\hline 279.1577 & & & 1 & 1832256 & & \\
\hline 280.1614 & & & 1 & 330125.53 & & \\
\hline 301.1395 & & & 1 & 983859.81 & & \\
\hline 452.2624 & & & 1 & 437062.19 & & \\
\hline
\end{tabular}

MSMS Spectrum

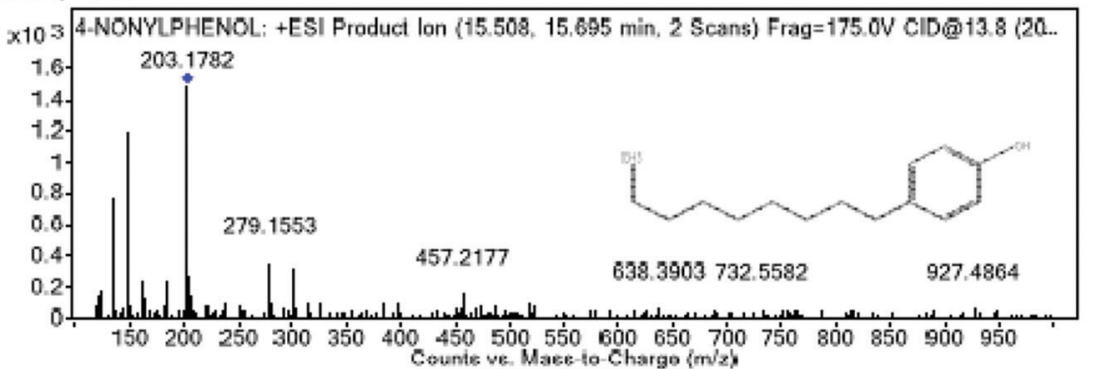

MS/MS Spectrum Peak List

\begin{tabular}{|c|r|r|}
\hline$m / z$ & $\mathbf{z}$ & Abund \\
\hline 133.0997 & & 753.21 \\
\hline 135.1134 & & 187.92 \\
\hline
\end{tabular}

Compound Structure

\begin{tabular}{|r|r|r|}
\hline 147.1155 & 1 & 355.78 \\
\hline 149.022 & & 1185.94 \\
\hline 161.1329 & & 233.46 \\
\hline 183.1153 & 1 & 229.52 \\
\hline 203.1782 & 1 & 1490.24 \\
\hline 204.1786 & 1 & 262.06 \\
\hline 279.1553 & 1 & 349.21 \\
\hline 301.1377 & 1 & 306.81 \\
\hline
\end{tabular}<smiles>OC1CCC(CCCCCCCCCl)CC1</smiles> 
6. Lagochilin

\begin{tabular}{|l|l|l|l|l|l|}
\hline Compound Label & Name & $\mathrm{m} / \mathrm{z}$ & RT & Algorithm & Mass \\
\hline LAGOCHILIN & LAGOCHILIN & 361.2357 & 19.256 & Auto MS/MS & 356.2571 \\
\hline
\end{tabular}

MS Spectrum

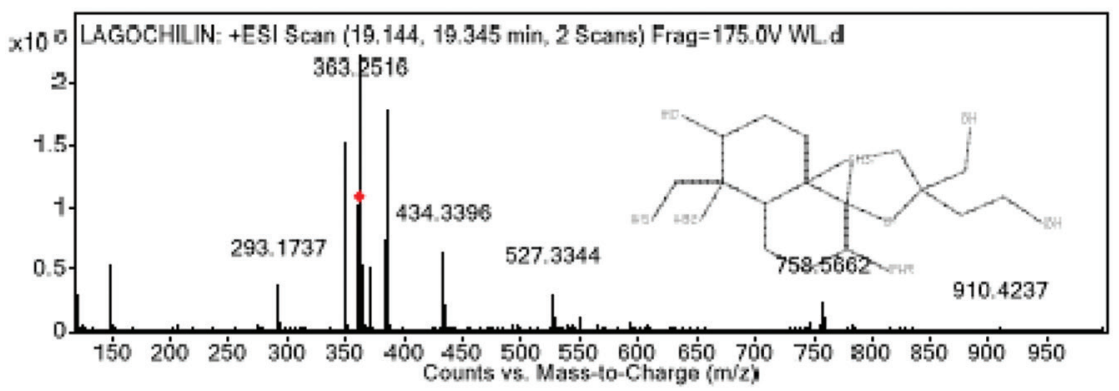

MS Zoomed Spectrum

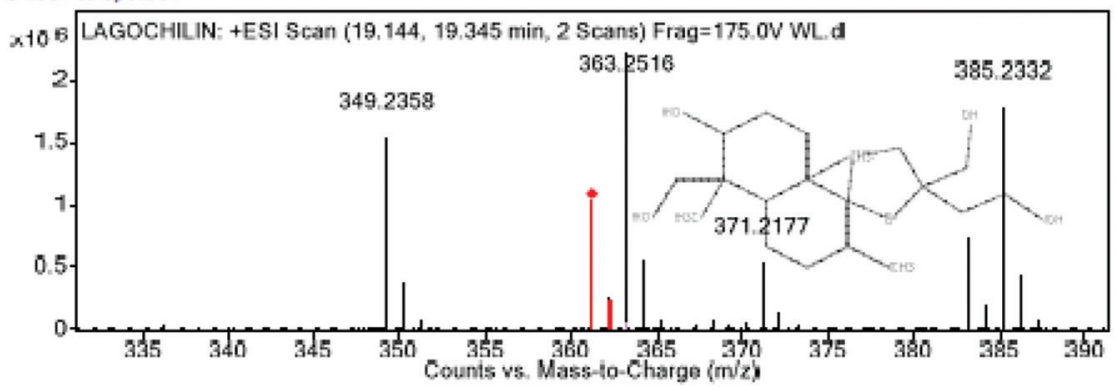

MS Spectrum Peak List

\begin{tabular}{|c|c|c|c|c|c|c|}
\hline$m / x$ & Calc $\mathrm{m} / \mathrm{z}$ & Diff(ppm) & $z$ & Abund & Formula & Ion \\
\hline 149.0226 & & & 1 & 531516.38 & & \\
\hline 349.2358 & & & 1 & 1517979.25 & & \\
\hline 361.2357 & 361.2349 & -2.04 & 1 & 1012787.69 & $\mathrm{C} 20 \mathrm{H} 36 \mathrm{O} 05$ & $(\mathrm{M}+\mathrm{Na} 3)+[-\mathrm{H} 2 \mathrm{O}]$ \\
\hline 362.2394 & 362.2383 & -3.01 & 1 & 250942.03 & $\mathrm{C} 20 \mathrm{H} 3605$ & $(\mathrm{M}+\mathrm{Na})+[-\mathrm{H} 2 \mathrm{O}]$ \\
\hline 363.2516 & & & 1 & 2217978.25 & & \\
\hline 364.2551 & & & 1 & 536658.31 & & \\
\hline 371.2177 & & & 1 & 514172.75 & & \\
\hline 383.2176 & & & 1 & 737135.63 & & \\
\hline 385.2332 & & & 1 & 1768841.13 & & \\
\hline 434.3396 & & & 1 & 644861.63 & & \\
\hline
\end{tabular}

MSMS Spectrum

x10 4 LAGOCHILIN: +ESI Product lon $\langle 19,155,19,357$ min, 2 Scans) Frag=175,0V CIDQ26,4 (361,236..

4. 149.0224

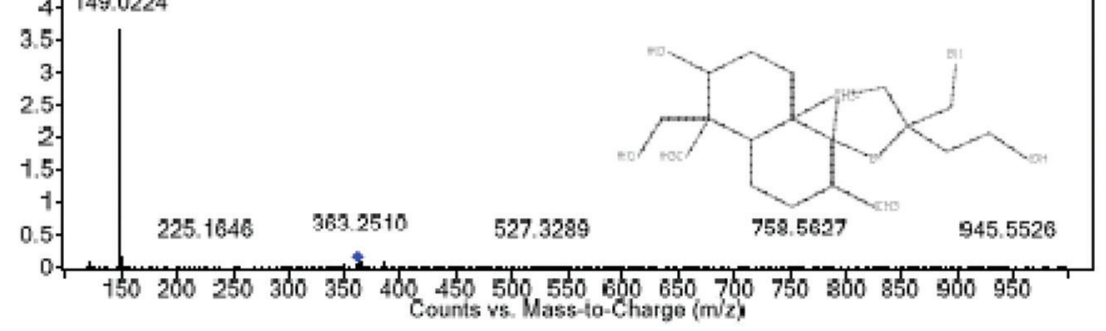

MS/MS Spectrum Peak List

\begin{tabular}{|r|r|r|}
\hline $\boldsymbol{m} / \boldsymbol{z}$ & $\boldsymbol{z}$ & Abund \\
\hline 121.0309 & & 612.54 \\
\hline 149.0224 & 1 & 36511.01 \\
\hline 149.0695 & 2 & 234.36 \\
\hline 150.0265 & 1 & 1503.41 \\
\hline 293.1716 & & 327.53 \\
\hline 349.2354 & 1 & 342.35 \\
\hline 361.2352 & 1 & 516.03 \\
\hline 363.251 & & 964.62 \\
\hline 364.2547 & & 6557.05 \\
\hline 365.2314 & 1 & 833 \\
\hline
\end{tabular}

Compound Structure<smiles>CC12CCC(CO)(CCO)C1CCC(O)C21CCC(O)C(CO)(CCO)O1</smiles> 
7. Ophiobolin A

\begin{tabular}{|l|l|l|l|l|l|}
\hline Compound Label & Name & $\mathrm{m} / \mathrm{z}$ & RT & Algorithm & Mass \\
\hline Ophiobolin A & Ophiobolin A & 399.2548 & 17.93 & Auto MS/MS & 400.262 \\
\hline
\end{tabular}
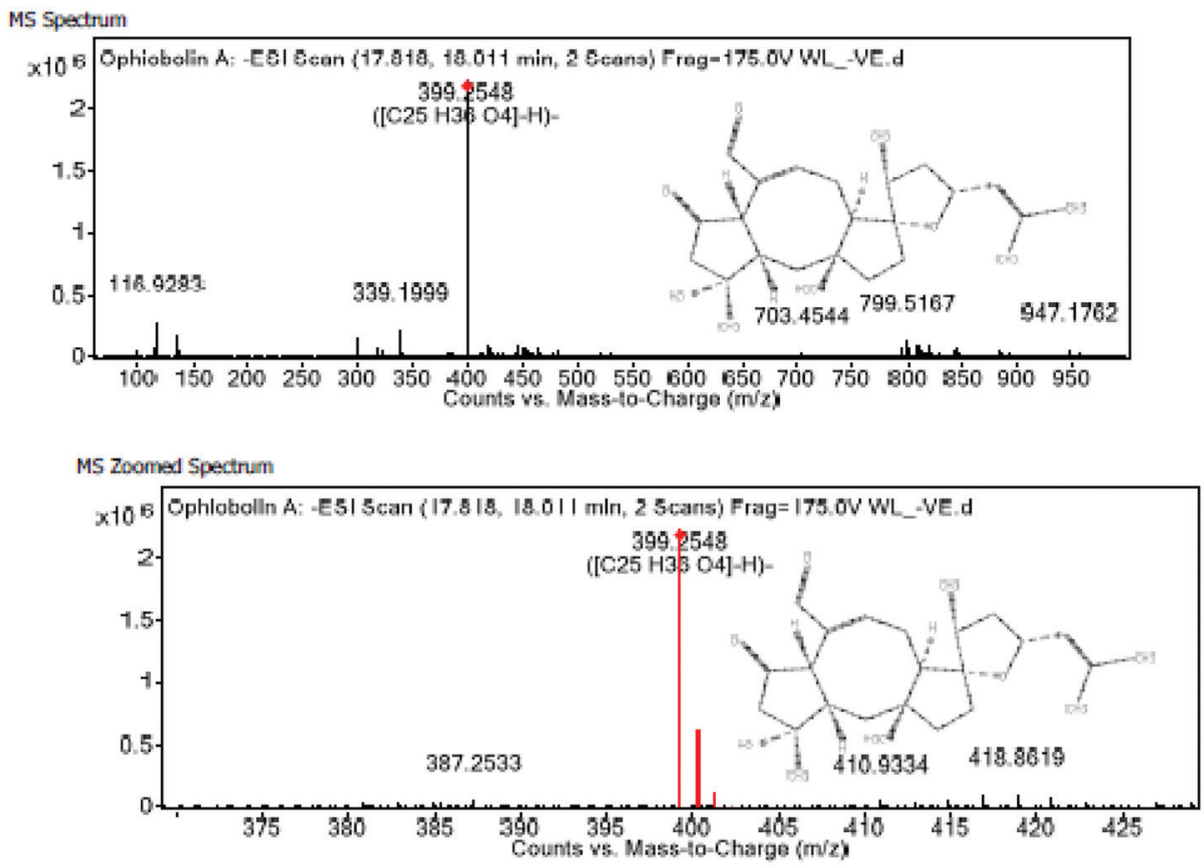

\begin{tabular}{|c|c|c|c|c|c|c|}
\hline$m / z$ & Calc $\mathrm{m} / \mathrm{z}$ & Diff(ppm) & $x$ & Abund & Formula & Ion \\
\hline 116.9283 & & & 1 & 275570.81 & & \\
\hline 134.8942 & & & 1 & 171447.81 & & \\
\hline 299.2016 & & & 1 & 144303.25 & & \\
\hline 339.1999 & & & 1 & 207582.75 & & \\
\hline 399.2548 & 399.2541 & -1.86 & 1 & 2234338.25 & $\mathrm{C} 25 \mathrm{H} 36 \mathrm{O} 04$ & $(\mathrm{M}-\mathrm{H})-$ \\
\hline 400.258 & 400.2575 & -1.33 & 1 & 603771 & $\mathrm{C} 25 \mathrm{H} 36 \mathrm{O} 04$ & $(\mathrm{M}-\mathrm{H})-$ \\
\hline 4011.2608 & 401.2604 & -1.06 & 1 & 85282.78 & $\mathrm{C} 25 \mathrm{H} 36 \mathrm{O} 4$ & $(M-H)-$ \\
\hline 446.8942 & & & & 94096.88 & & \\
\hline 799.5167 & & & 1 & 127223.9 & & \\
\hline 809.1836 & & & 1 & 95244.16 & & \\
\hline
\end{tabular}

$$
\text { MSMS Spectrum }
$$

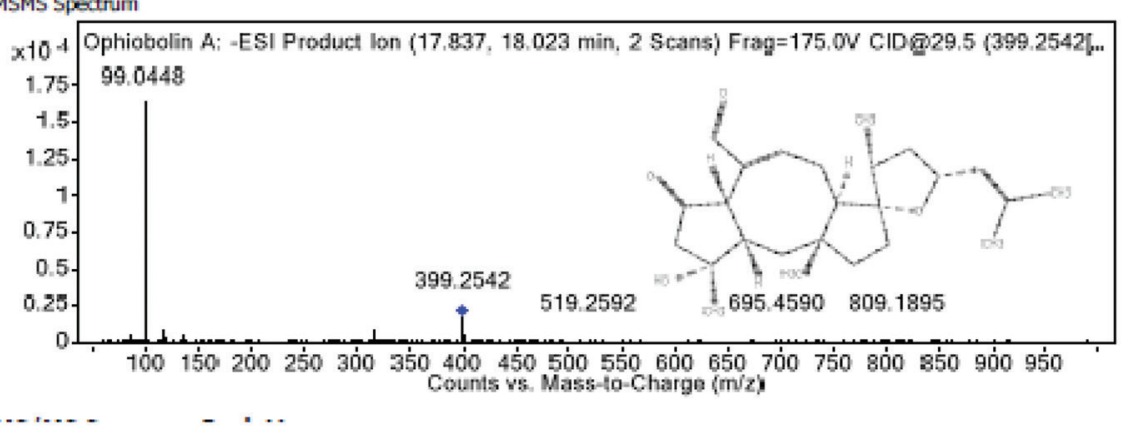

MS/MS Spectrum Peak List

\begin{tabular}{|r|r|r|}
\hline \multicolumn{1}{|l|}{$\boldsymbol{m} / \boldsymbol{z}$} & $\boldsymbol{z}$ & \multicolumn{1}{l|}{ Abund } \\
\hline 87.0448 & 1 & 527.62 \\
\hline 99.0448 & 1 & 16310.47 \\
\hline 99.0827 & & 776.43 \\
\hline 100.0481 & 1 & 727.23 \\
\hline 101.0592 & 1 & 712.87 \\
\hline 116.9283 & 1 & 657.64 \\
\hline 134.8939 & 1 & 480.81 \\
\hline 317.2113 & 1 & 662.97 \\
\hline 399.2542 & 1 & 1563.35 \\
\hline 400.2568 & 1 & 393.73 \\
\hline
\end{tabular}

Compound Structure

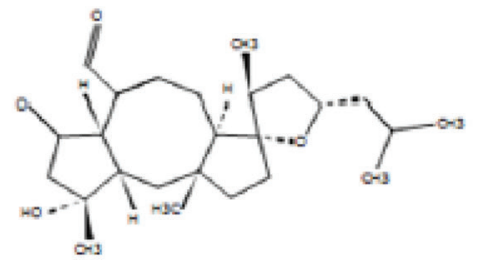

